12, 510 ('63).

61) F. F. Davis: Biochim. Biophys. Acta, 42, 1 ('60); 62) S. Paléus, J. Porath: Acta Chem. Scand., 17, 57 ('63); 63) F. G. Lootiens, C. K. de Bruyna: Naturwissenschaften, 50, 614 ('63)； 64）飯田克平, 渡辺 哲, 江上不二夫：生化 学, 32, 284 ('60); 65) J. Porath, K. Störiko: J. Chromatog., 7, 385 ('62); 66) S. W. Bailey, R. H. Hackman: ibid., 8, 52 ('62); 67) A. Seniów: ibid., 3, 586 ('60); 68) 小延鑑一：分化, 12, 131 ('63); 69) N. F. Hollinger, R. K. Lansing: J. Chromatog., 5, 121 ('61); 70) L. N. Werum, H. T. Gordon, W. Thornberg: ibid., 3, 125 ('60).

71) E. W. Bermes, Jr., H. J. McDonald: J. Chromatog., 4, 34 ('61); 72) 永田絢子: 農化, 35, 8('61); 73) Z. Fidler, J. Vacík, J. Dvořák, O. Grubner: J. Chromatog., 7, 228 ('62); 74) J. Schraml, J. Vacik, O. Grubner, J. Dvořák: ibid., 9, 154 ('62); 75) J. Barrollier: ibid., 4, 99 ('61); 76) D. A. Burns, O. J. Pollak: ibid., 11, 559 ('63); 77) O. Horesovský, J. Dupal, I. M. Hais: ibid., 9, 260 ('62); 78) S. F. St. Groth, R. G. Webster, A. Datyner: Biochim. Biophys. Acta, 71, 377 ('63); 79) S.K. Shukla, M. Lederer: J. Chromatog., 9, 255 ('62); 80) 河村正一：分化, 10, 975 ('61); 同上, 11, 814 ('62).

81) W. W. Thornberg, L. N. Werum, H. T. Gordon: J. Chromatog., 6, 131 ('61); 82) T. H. J. Huisman, A. E. Dozy: ibid., 7, 180 ('62); 83) 野並慶宣：農化，37，602('63)；84）佐藤 肇： 生化学, 32, 39 ('60); 85) Y. Minoda, K. Yamada: Agr. Biol. Chem., 27, 806 ('63); 86)
西田 ₹ツエ：生化学，32，801 ('60)；87） 田中正生, 加藤 洋，木下祝郎：農化， 35, 1385 ('61); 88) Z. Stránský: J. Chromatog., 10, 456 ('63); 89) S. Ito, Y. Oshima: Agr. Biol. Chem., 26, 156 ('62); 90) A. W. Sangster: J. Chromatog., 3, 92 ('60). 91) R. Piras, E. Cabib: J. Chromatog., 8, 63 ('62); 92) M. Szwaj, M. Mánski: ibid., 3, 425 ('60); 93) M. H. Bickel, D. Bovel: ibid., 8, 466 ('62); 94) 太出尚志: 生化学, 33, 320 ('61); 95) F. H. Carpenter, S. L. Hayes: Biochemistry, 2, 1272 ('63); 96) F. Dobici, G. Grassini: J. Chromatog., 10, 98 ('63); 97) D. Gross: ibid., 5, 194 ('61); 98) D. Gross: ibid., 10, 221 ('63); 99) H. M. Klouwen: ibid., 7, 216 ('62); 100) E. Heilbronn, B. Carlsson: ibid., 4, 257 ('61).

101) L. Braun: Biochem. Z., 339, 8('63); 102) 磯 俊男: 生化学, 33, 103 ('61); 103) H. T. Yang, M. R. Shetlar: Anal. Chem., 35, 2224 ('63); 104) Z. Pučar, Z. Jakovac: J. Chromatog., 3, 477('60); 105) Z. Pučar, Z. KonradJakovac: ibid., 9, 106 ('62); 106) A. L. C. Wallace, K. A. Ferguson: ibid., 4, 233 ('61); 107) J. Sawada: Agr. Biol. Chem., 27, 677 ('63); 108) 根来秀夫：生化学, 32,306 ('60); 109) R. F. Peterson, L. W. Nauman: J. Chromatog., 4, 42 ('61); 110) M. Eto, Y. Oshima: Agr. Biol. Chem., 26, 452 ('62).

111) S. Winsten: Anal. Biochem., 6, 404('63); 112) K. Wiek: J. Chromatog., 13, 111 ('64); 113) S. Patil, H.J. Evans, P. McMahill: Nature, 200, 1322 ('63).

\title{
9 ガスクロマトグラフ分析
}

武内 次夫 - 鈴木 正巳 - 石井 大道 - 鈴木 義仁

森 定 雄·角五 正弘・加藤 典彦*

本進歩総説は 1962 年から 1963 年の間の交献を主体 とし, 1964 年のもので気のついた重要なものは記載し た。

\section{$9 \cdot 1$ 全般について}

1962 年〜1963 年の 2 年間の進歩総説としてまずあげ るべきものは Anal. Chem. の本年 (1964 年) 4 月に 発刊された Annual Review ${ }^{186)}$ である.これによる と, ガスクロマトグラフィー（以下 GC と略す）は分析 化学のうち最も活発な分野の一つとして発展を続けてお

* 名古屋大学工学部工業分析化学教室 (名古屋市千 種区不老町)
り, 1962 年に 1860 以上, 1963 年に 1800 以上の文献 が印刷されている。

この間に出た単行本としては全般的に書かれているも のとして Dal Nagare, Juvet 共著のもの ${ }^{72)}$, Little-

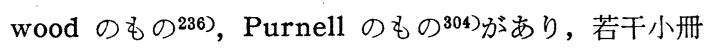
のものとして Ambrose, Ambrose 共著のもの ${ }^{12)}$,

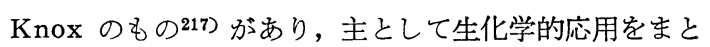
めたかなり大冊の Burchfield, Storrs 共著のもの ${ }^{54) か ゙ ~}$ ある.また, 西独の Kaiser の本が英訳され 3 冊として 発売された ${ }^{193)}$. Lewis による膨大な保持容量に関する 資料232), 1962 年 Canisius College Gas Chromatography Instituteで行なわれた講義のテキスト ${ }^{350)}$, 初 
学者用としての Miller の実験書264) も出版された. 邦 書としては佐藤による Keulemans の第 2 版の邦訳 ${ }^{318)}$, 武内, 高山共著によるすの361) が出版された. また，化 学の領域増刊第 3 集 ${ }^{190)}$, 第 4 集 ${ }^{191)}$, 第 5 集 ${ }^{192)}$ の GC $の$ 特集号が出版になった。

この間に行なわれたシンポジウムとして Michigan State University で行なわれた 1961 年の International GC48), Hamburg で行なわれた第 4 回 International $\mathrm{GC}^{379)}$, Leuna だ行なわれた東独第 4 回 $\mathrm{GC}^{13)}$ があり，その研究発表がとれぞれ単行本として発刊さ れた。その他のシンポジウムとして 1962 年の Brno Czechoslovakia $\mathrm{GC}^{180)}, 1962$ 年，1963 年の英国石油 協会の GC ディスカッションのインフォマルのもの11 237)239), Bordeaux に寺ける GCによる食物の分析の第 1 回国際シンポジウム317が行なわれた.

レビューの抢もなものは臨床化学 ${ }^{208)}$, 塗装 ${ }^{345)}$, 精

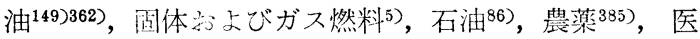

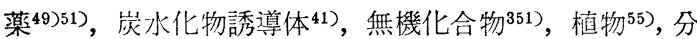
取 GC7) に関吉るもの，抢よび Chovin ${ }^{63)} や H^{3}$ Habgood ${ }^{153)}$ の書いた広範なものもある。

$\mathrm{GC}$ の月刊専門雑誌として 1963 年 1 月から The Journal of Gas Chromatography が出版された ${ }^{183)}$. Preston Technical Abstracts Co. は $5 \times 8$ インチの 大きさの GCアブストラクトのカードをオリジナルの報 交が出てから数週間以内に出方努力を続けている ${ }^{302)}$. また，往来から出版されていた GCのアブストラクト集 の追加本が 2 册出された。 1 冊は 1961 年のもの 883 を 収めたもので 1962 年に ${ }^{212)}$ ，他の 1 冊は 1962 年のもの 763 を収めたもので最近出版された ${ }^{213)}$.この本の特長は 題目と著者による完全な索引がある点である，GC に関 する出版物の 7000 以上の目録も Signeur により製作 された ${ }^{334)}$. また近く Preston と Hyder によっても 出版される予定である299)。この後者の 1963 年 1 月か ら 12 月までの補足の本はすでに発刊された ${ }^{301)}$. The Journal of Chromatography にも交献欄があり，数 語の説明のついた題目が記載されているが，とりあげて いる文献数はこの分野の研究の 50 ～60\% 程度である. 米国の特許は 1955 年には 1 個であったものが，1962 年 には 50 個に達している.この特許については Preston と Hyder によって完全なものが出版されている300). 最近の特許については The Journal of Gas Chromatographyにも記載されている. 日本分析化学会 GC データ委員会発行のパンチカード $(\mathrm{GCDC}){ }^{274)}$ は米国 発行の GC パンチカードと異なってガスクロマトグラム ならびに測定条件在記載しておう，外国への輸出も考慮
して英交で書かれているが，1964 年 3 月で 2000 枚に達 した。

\section{$9 \cdot 2$ 充てんカラム}

9·2・1 カラム理論 カラム理論に関する最近の進歩 が Giddingsによって紹介されている132)，それによれ ば Van Deemter の HETP 式で特にA項, C項がさ らに検討され，カラムの複雑な構造的因子（内部の固体 表面㧍よび液相の構造）が，構造-非平衡の近似によっ て HETP 式に導入された。 その結果 HETP 式はます ます複雑化したが，ガラスビーズのような簡単な充てん カラムの段高を予測しうるようになり，計算值と理論値 のかなり良好な一致が得られている ${ }^{140)}$. この理論は昇 温ガスクロ 129) および不均一カラムの段高理論131), 分析

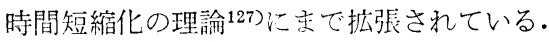

不均一な液相の分布状態についても研究され ${ }^{128)}$, 液相 での物質移動項の係数が求められた ${ }^{2882289)}$. 気相での軸 方向拡散,気相での非平衡, 液相での非平衡に関する 3 変

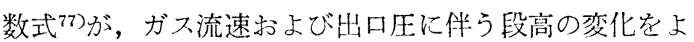
く説明でき，また実験的にも吟味され，その結果と理諭 值とがよい一致を示している.Van Deemter-Jonesの 式についても検討された ${ }^{71)}$. 気相での物質移動が非平衡 の理墖130からと, “Wall Effect”から諭ぜられた146).

か流拡散をカップリング理論から説明(133), 気相拡散 の寄与および流速の影響が HETP 式のA項に導入され た。 か流拡散の機構を, からのチューブでの TaylorGolay 効果と関係づけた報告もある108). 空気ピークの 実験的研究 207）により，GCに注ガス流速に無関係な変 数はなく，気相での物質移動抵抗もガス流速に影響され ることが見いだされている。古典的なか流拡散の考え も，カップリング理論に基ゔくか流拡散も実験的には注 とえど論証がないということが結諭されている218) が， 一方，古典的なか流拡散の䛊り䘮指摘し，只流拡散の力 ップリング理論を強調している報告141)もある.

大口径カラムの理論的研究が, ガス流速の変化, 横方 向への拡散, カラム断面での液相の占める面積の变化尔

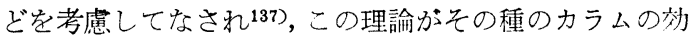
率を増すために利用されている136).

他の理論的研究として, GLC（気一液相クロマトグラ フィー）における一様なフィルムモデルを考えての取り 扱い124), GCの推計学的理諭にラプラス変換を適用した もの 248)197)，一次元的なカラムモデル222)，父液界而での 物質移動抵抗についての研究 ${ }^{206)}$ などがある。また，カ ラム効率と分離に関して最もよく用いられている式がさ らに検討され，実際的なカラムについての実例が揭げら 
れている ${ }^{97)}$ ）GSC（気-固相クロマトグラフィー）の理 論的な研究もなされ ${ }^{324)}$, 混合吸着扸についての報告があ る122).

低液相カラムで問題てなる気相, 液相, 固相の 3 相 の存在が論ぜられ205), 匃液界面での過剩溶質に対し， Gibbs の式が計算された253).

カラム圧の影響が分析時間短縮化の立場から論ぜら れ138), 特に入口压と出口压の比が大きい場合について検 討されている.その結果出口压がほとえど0で，入口圧 の低いほど分析時間短縮化に有利であることが示唆され ている.また，カラム圧の HETP への影響161) につい ても論ぜられている.

温度による影響が，GLC および抎散係数についてな されている1343227).

非対称ピークについての報告もなされ(15)96)，局部的な 温度変化に伴うピークのゆがみについて理論的に报われ ている325)

試料導入時間とカラム効率に関与る式が誘導されてい る150)。滑剩なカラム死容量についての検討もなされ た375).

カラムの分離能についても報告され84), “ effective peak number” が分離の評定に提案されている174). ピーク面積比が 異なる 2 成分のピークの分離に 関する Glueckauf の因子が，もっと広範囲のピーク面積比に 適用できるように改められた ${ }^{315)}$. 理論段数およびピー ク面積の計算に必要なピーク幅の最適測定法についても 検討された816).

$9 \cdot 2 \cdot 2$ 液相 新しい液相として $\beta, \beta^{\prime}$-オキシジプロ ピオニトリルに匹適する極性をもつ $\mathrm{N}, \mathrm{N}^{\prime}$ ービス（2-シ アノエチル)ホルムアミドが提案された ${ }^{144)}$. 前者は $70^{\circ} \mathrm{C}$

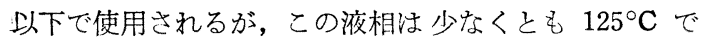
も安定であって極性物質にすぐれた選択性を示吉液相と して使用できる.シクロへキ+ンジメタノールのコハク 酸ポリエステルがステロイドにたいしてネオペンチルグ リコールのコハク酸エステル (N. G.S.) と同程度の選 択性をもつ液相であり ${ }^{343)}$ ，シリコンポリマー SE30 と の混合液相を用いて各種ステロイドの分離ができる219). また，ケトステロイドに選択性を示す液相としてエポン 樹脂 1001 (Shell Chem. Co.) も使用されている391).

シリコン油にシアノアルキル基学導入すると極性をも つようになり，かつ䆃入した期の数によって極性を任意 にもたせることができる。ニトリルシリコン油を液相と してオレイン酸の立体異性体を毛細管カラムで分離し チ235). 芳香族炭化水素類の分離に効果の西る液相とし て，1，2，3-トリス(2-シアノエトキシ)プロパンがある.
この液相でキシレンのアルキル置換体の $\mathrm{C}_{6} \sim \mathrm{C}_{10}$ の炭素 数をもつ異性体の分離が ${ }^{66)}$, また, “ベントン 34 ” 力 ラムではキシレン異性体の分離がよくなかったが，“べ

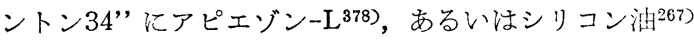
を添加したものを用いることによって芳香族炭化水索の 分離が良好となった。ノニルフェノールも含酸素化合物 の分析に液相として使用された ${ }^{373) . ~}$

脂肪酸の分離には $\beta$-シクロデキストリンのアセチル, プロピル，ブチルおよびバレルエステルを液相として用 い, 各液相について脂肪酸メチルの分離についての検討 がなされた ${ }^{319}$ 。 また，脂肪酸をエステル化しないで， そのままガスクロマトグラフィーを行なった例として， ポリエステルにリン酸を添加した液相で 炭素数 10〜18 を262)，D. O.S. にベヘニン酸を添加した液相で低級脂 肪酸1199をそれぞれ分析している。

無機物の溶融塩を液相としてガスクロマトグラフィー を行なった例として，沸点の近接した含窒素有機化合物 であるピリジンとルチジン，ピコリンなどの異性体のそ れぞれの分離にナトリウム, カリウム, リチウムなどの 硝酸塩の $12.2 ， 54.5,27.3$ の共融混合物老液相として 用いた ${ }^{160)}$. 宝た，硝酸銀注オレフィン類に選択性を持 つので，硝酸銀をクロモソルブ $\mathrm{P} や \mathrm{~W} に$ 保持させてオレ フィンーパラフィン混合物からオレフィン類を融) また オレフィン類の分析に 硝酸銀ーグリコール液相を用いて いる166).

二つの極性の異なる液相から作製した混合液相カラム の性質についての研究も行なわれ，異なる液相它担体に それぞれ别個に保持させ，カラムに充てえする際に混合 したものと，あらかじめ両液相を混合して担体保保さ せたカラムとの比較を行ない，両方法に大差のないこ と255) から混合液相カラムについての極性の予知や，保 持能は単一液相カラムで求めたものから予知できる.

液相の分類も行なわれ，多数の普通使用される液相の 極性が定められた250)。 また，未知液相カラムについて の極性のきめ方や238), 与元られた物質についての液相の 選択の予知も行なえる.液相を電子供与体と受容体など の性質からの分類50)や，種々の液相之溶質について溶質 分子と液相分子間の相互作用について考察が行なわれ た403).

カラム中の液相の劣化について, 液相の触媒反応, 不 純物の存在，重合や橋ふけなどの考察がある204).

液相によるカラム使用の際の限界温度についてガスク ロマトグラフによって検討され298)， $0.1 \mathrm{~mm}-\mathrm{Hg}$ の蒸 気圧を示す温度がその液相の使用上の限界温度になる。

液相の担体へのつけ方についても研究され，碎けやす 


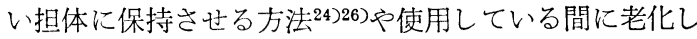
たカラムの回復方法 ${ }^{286}$ につつての提案がある.

$\mathbf{9} \cdot \mathbf{2} \cdot \mathbf{3}$ 担体 液相を保持させる担体は吸着性や接触 反応を起こさないほうがよい。このため, 良好な担体を 得るた別の条件の㭘討や担体の物理的な性状について調 ベられた285).

担体の処理については, 担体の酸㧍よびアルカリ処理 の効果について検討されたり ${ }^{43)}$ ，ヘキサメチルジシラザ ン(HMDS) と処理して担体表面に露出しているシラノ 一ル基による活性点の不活性化の考察290) P HMDS を カラム中に注入することによって迅速に不活性化処理が できること 24)，また，液相を担体に保持させるとき，ポ リビニルピロリドンを添加する ${ }^{376)}$ 方法などの研究があ る.

特に, 低液相カラムにおいては担体の性質に基ゔく寄 与が大きくなる.そこでティリング現像の観点から, 液 相を保持させるとき, 少量のカーボワックスなどの極性 物質を添加することによってテイリングを減少させるこ とができた ${ }^{3599}$. また，多くの担体について，低液相力 ラムの場合の研究があり ${ }^{358)}$, テイリング減少剤の添加に よる良好な担体は C-22であることや，そのほか，担体 として，バイコル粒311)，多孔質ポリエチレン30)を用いた 研究がある.

カラムの性能を高めるためには, 担体の表面積を増加 させることも必要である. ガラス粉末（60～ $80 \mathrm{mesh})$ に“スパーフロス” (ケイソウ土粉末)を 1 1.5\% 添 加することによって，カラムの段高が $4.0 \mathrm{~mm}$ から 0.8 $\mathrm{mm}$ となった ${ }^{79}$.

$\mathbf{9 \cdot 2 \cdot 4}$ 吸着剤 吸着剂に有機液相を加えていくに従 って GSC から GLC への移行が考察された，C-22 に 対して, 液相として DOS が $0.5 \%(\mathrm{w})$ 以上では GLC となり，0.5\%(w) 以下では GSCであって，GSC の場 合 DOS がティリング減少戍となることがわかった ${ }^{358)}$.

芳香族炭化水素の分析に吸着片として硝酸銅ピリジン 錯塩やアンモニウム塩などを使用した報告310), 瀻維状の ベーマイトを用いて低沸点の炭化水素や炭化水素塩素化 物を分析した報告 210$)$, 多孔質のガラス粒を含酸素有機化 合物たとえば，エタノールやアセトンで処理して，炭化 水素類の分析を行なった報告 244 出ある.

二酸化マンガンを吸着䯇に用いて酸素と窒素ガスの分 離ができる. 両ガスの分離はカラム温度によって变化 し，約 $850^{\circ} \mathrm{C}$ と $1000^{\circ} \mathrm{C}$ でそれぞれ分離が極大となっ た.この温度はそれぞれ三二酸化マンガン，四三酸化マ ンガンの安定温度であることから，これらの吸着戍によ

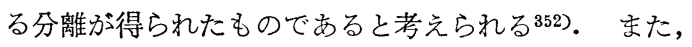

空気中の酸素と窒素の分離はモレキュラーシーブ $5 \mathrm{~A}$ と クロモソルブ (赤) でもよい44).

グラファイトを吸着剤に用いて，ポリエチレン粒に保 持させたものでフロロ炭化水素類の分析を行ない，毛細 管カラムで分離できなかったものも，この吸着剤で良好 な結果を得ている295)。

モレキュラーシーブ5A を炭化水素類の分類に用いた 研究9)があり，モレキュラーシーブ5A をつめたカラム を分離カラムの前に連結し, 高分子量の $n$-パラフィン 類と分枝したパラフィン類との類別ができる.モレキュ ラーシーブについての性質や, 総説が書かれている167).

$9 \cdot 2 \cdot 5$ キャリャーガス キャリャーガスについての 最近の報告は少ない。

キャリヤーガスの種類によっておこる保持の差異78), 減圧下での GC 操作 ${ }^{381}$ おおよびイオン化検出器を用いた 場合のカラム停滞時間の測定 ${ }^{145)}$ について, わずかな報 告がなされた。

9.2.6 試料導入 種々の試料導入法による GC の応 答の理論的な研究がなされ, 定量分析, 分取クロマト, カラム現象の研究, 工業的プロセス流路の監視などの応 用が検討されている307).

$5 \sim 20 \mathrm{~m} l$ の導入容積をもつ安価なガス採取バルブが 考案された ${ }^{85}$ )。微量の固体試料を注入する装置が243), 生 物体中のステロイドホルモンの定量分析などに使用され た．反応しやすい固体試料を無水の条件下で導入する方 法92), 高分子熱分解の際に, 熱分解残余物などの正確な 重量測定が可能な試料導入装置 297$)$ ，また $\mu \mathrm{g}$ 量の試料導 入に適したスプーン法233088)などがある。

溶液中にキャリヤーガスを通し，溶けている気体成分

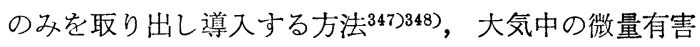
物を定量するための捕集装置 33 , およひび採取濃縮する装

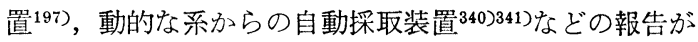
ある.ガス中に存在する比較的高沸点の少量化合物を定 量するために, 試料管での吸着を防ぎ試料の輸送を簡単 にした装置69)が用いられた。真空系での少量の気体試料 が, GC 装置へ功妙に導入さ机た ${ }^{387}$.

キャピラリークロマトグラフへの試料導入法について も報告されている.ガス分析用の特殊なバルブが考案さ れた ${ }^{2699}$. 試料を不揮発性の溶媒に溶かし，この中へ不 活性ガスを通して採取する方法181) は, 溶液の研究に有 用である.プランジャータイプの装置を用いて, $10^{-2} \mu \mathrm{g}$ の試料を注入することができた ${ }^{107) . ~}$ 流動しているガス を分割して，キャピラリー GC 装置に導入する方法65方 述べられているが，大口径の open tubular カラム它使 用すれば，試料を直接注入できる406)。試料容器の補正 
がカラムへの連結部分の容積它も含めて, 従来よりも迅 速に行烄われている305). その他にも種々の試料注入装 置が工夫された22246)。循環かつ連続的な採取装置が，大 気压以下の系のた的汇開発された ${ }^{59}$.

注入部分に蓄積与る不揮発性物質の除去 ${ }^{64) 268)}$, 予熱七 ーターのよごれとその影響338), 注入部分のヒーターでの 酸化テルペンの分解76)尔に゙についても研究された。

試料といっしょに反応試薬を導入し, 適当な注入部分 の温度で交換度応起させ, 反応生成物を GC 装置へ送 り込气法があり，長鎖有機酸の注入部でのエステル

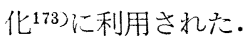

多量の試料を導入する際に，力ラム効率の低下抢よび ピークのつぶれが起るが，この欠点を除くためにカラム の最前端に大口径充てんカラムを付け, 効率を增すこと ができた3311.ただし全体のピーク面積は減少する。

$9 \cdot 2 \cdot 7$ 分離成分の捕集 $\mathrm{GC}$ の分離物を他の機器例 えば IR，マススペクトル，NMR などと併用するこ とによって一段とその分取成分の同定を確実にできるこ と，また物質の精製の手段として GCにより純物質を採 取するなどの目的で GC よりの各成分の捕集方法につい て研究されている.

低温度における充てんトラップの効果 ${ }^{386)}$ やキャリヤ 一ガスにアルゴンを用いて液体窒素中にキャリヤーガス と同時に各成分を捕集する方法 ${ }^{349)}$ ，IR のための簡単な 方法147)などがある。このほか，赤外全反射吸収スペク トル (ATR)のためには，屈折率の大きな物質上に付着 させることができる.

また，トラップ山に凝維させるとき，キリ状になって 捕集が困難となる。捕集㻭孛あげるた如に，電気的な凝 縮器 367 を用いる力法や，温度差のあるトラップ7333423348) 365)，トラップを交互に加熱したり，冷却したりしてキり 状となるの觉防止するエ夫がなされている320)。これら の各方法で 90〜 95\% 程度の捕集率となる。

凝縮させずにケイ砂中に保持させ, 他の機器に導入す る法 ${ }^{89}$ も提案されている.

\section{$9 \cdot 3$ 毛細管カラム}

過去 2 年間の毛細管カラムに関玄る就をな研究は次の 三つに要約される。宁な和ら試料注入量を增加させるた めのカラム内壁の收着性能あるいは液相叙布量に関する 研究, いろいるな吸着物質をつめた毛細管カラムの研 究，打よび毛細管内径定従来より大きくしたカラムの研 究である.

銅製毛細管の内面を金，銀，白金または水銀でメッキ することにより，その表面沈 GSC または GLC 上有用
な吸着性を示す405)。 また重クロム酸カりウム, 塩化ナ トリウム, シリカ, エポキシ樹脂なども毛細管内壁の性 質をかえるのに有効である・アルミニウム毛細管の内壁 にアルミニウムの活性酸化被膜を作ったカラム注液体を 塗布した毛細管カラムと同じ分離効率をもち, 活性アル そナの充てえカラムに匹敵する分離性能をもつ291).そし てこのカラムの利点は, 検出器にノィズを生じはい限り 高温に使用可能なことおよびカラム寿命が長く再活性が 容易なことである。毛細管カラムの低効率法液相の不均 一な分布と non-wetting な性質に起因し, 特にガラス 管を用いた場合に著しいといわれている。したがって金 属, ガラス, 合成樹脂など毛細管によく用いら礼る材料 の表面での各種固定相液体の接触角 $\theta$ を測定し, 表面張 力 $\gamma$ 対して $\cos \theta$ を図示して最大值 $\gamma_{\mathrm{c}}$ を求为る. こ の $\gamma_{\mathrm{c}}$ 注毛細管材質と液相を選択する際の評価の尺度に 用いることができる106)。液相を含ませた担体の薄い層 を毛細管内壁に作ったカラムは通常の毛細管カラムより 分離能がすぐれている場合があり, 試料注入量を多く与 ることもできる156)157)。このカラムは，たと光ばグラフ フイト化したカーボンブラック, アルミナ, 活性酸化鉄, シリコンカーバイドなどの担体を三エチレングリコー ル, スクワランなどの液相とともに溶剤に懸濁させ, こ れを毛細管に注入し, 特別な炉の中で溶郕を蒝発させて 作る. 同じような試みは炭化水素の分離に用いられ, Nalcoag-1022 (Nalco Chem. Co.,-コロイド状シリカの $22 \%$ イソプロピルアルコール-水混合溶液）をデルリン 毛細管に叙布してペンタンとへキサンの異性体 8 成分の 分離が室温で行なわれ，ピークは鋭敏でテーリングも小

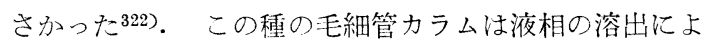
って生ずるトラブルがないため, 高感度検出器を用いた 分析汇適している. $0.04 \mathrm{~mm} \phi$ のスクワランを叙布した ガラス玉老つ奶た長さ $2 \mathrm{~m}$, 内径 $0.25 \mathrm{~mm}$ の毛細管カ ラムで 1000 段, 同じく内径 $0.5 \mathrm{~mm}$ のカラムで 2800 段の理論段数がメチルシクロヘキサンの場合に得られ た ${ }^{58)}$.内径の大きい毛細管カラムは効率が高いことと試 料注入量党多くできることが特長で，充てえカラムの 利点々通常の毛細管カラムに近い分離效率をもってい る306).このカラムは压力こう配を無視できるので，分 離効率をあげるため枋をムを長くすることができ，試 料分割器を用いることなく直接試料を注入することが可 能であり，熱伝導型検出器を用いることもできる983323) 406). したがって，イオン化検出器を用いる場合は試料 量を増して微量成分の検出が可能となる. 内径 $1.0 \mathrm{~mm}$ の毛細管カラムのキャリヤーガス流速および被膜の厚み の影響, 分離効率, 液相量についても詳細に研究されて 
いる182).

ある物質に対し同じ理論段数をもつ毛細管カラムと充 こえカラムを比較した場合, 分離度は後者のほうが高 く，蒸気圧が高くなるほどその差は著しくなる・このた わ相対揮発度に無関係に成分分離の程度を示吉尺度とし そ, transfer unit に対する相当高さ $\mathrm{H}_{\mathrm{OG}}$ の概念が考

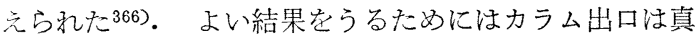
空に保つべきであると Giddings は最小時間操作の理論 の中で述べて扔り ${ }^{127)}$ ，このことを確認する研究も報告さ れている380)，毛細管カラムと充てんカラムの空気のピ ークの示す挙動からこれらのカラムの理想形からずれる 性質に関する知見がえられ，担体の研究に役立つこと がわかった276)。この汸か，HETP に関する実験值と Golay なたは Khan の式心ら得られる理論值との比較 による気相および液相中の物質移動の抵抗 ${ }^{165)}$, 多孔性の 層老有する毛細管カラムの HETP ${ }^{143)}$ の研究がある.

ふらの銅カラムが香料物質によい分離能を示し ${ }^{296)}$, 遊 離脂肪酸のテーリングは $10 \%$ trimer 酸と $0.4 \%$ ジノ ニルナフタレンジスルホン酸のトルエン溶液を毛細管に 塗布することによって除かれた ${ }^{25)}$. 毛細管カラムの洗浄 および塗布の簡単な方法が開発され ${ }^{171)}$, 充てんカラムに 使われている backflushing の操作を水素炎イオン化検 出器を備えた毛細管カラム GCに用い, 検出器感度の 向上と検出器内の dead volume の減少に有効であっ た109). 希勫された炭化水素混合物 $\left(99.8 \% \mathrm{~N}_{2}\right)$ の分析 に毛細管カラムを備えた昇温 GCが用いられ，保持容量 の標準偏差は $\pm 1.8 \%$ である ${ }^{245)}$. GC の検出器として

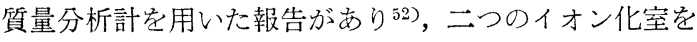
もった質量分析計に毛細管カラムからの溶出物を導入 し, 一方のイオン化室は定量分析用検出器として, 他方 は定性分析用検出器として使用された。同じような研究 がほかでも試みられている380)。

\section{$9 \cdot 4$ 検出器}

新しく開発された検出器に関して Schomburg らに よる交献がある230)321)。

$9 \cdot 4 \cdot 1$ 水素资イオン化検出器 水素炎イオン化検出 㼡はもっとも一般的な高感度検出器として現在わが国で も広く使用されているが，この検出器は無機ガスにはほ とえど感度がなく，対象汢有機分に限定される．この検 出器に対する相対感度が多くの異なった有機物に対して 求內られ，同族体においては炭素数との間に直線関係が 成立し95)，14～52 の偶数炭素原子を有する崖化水素， アルコールでは後者は前者の 0.5 炭素原子だけ感度が低 いことが確められた28r)。 また, 脂肪酸メチルエステル
についても同様の実験がなされた71)、濃度とピーク面䅡 の間の直線性の検討も行なるれた69). 検出器の試作に関 する報文も見られる115)1173265)。炎に直接触れないように 炎に対し直角においた電極究用いて良好な結果が得られ た229). 2 極， 3 極の水素炎イオン化检出器の比較に関子 る研究もある263).

$9 \cdot 4 \cdot 2$ 放射線イオン化検出器 アルゴンイオン化検 出器は無機ガスに対し感度はわるふったが, 短い path の検出器它低電圧で操作少ることにより, 酸素, 窒素の $10^{-11} \mathrm{~mol} / \mathrm{sec}$ 程度の検出が行なわれた ${ }^{234) 329}$. $\alpha$ 線源 として RaF の銀板上への電着による線源調製法 ${ }^{355}$, それを用いた検出器の試作も行なわれた ${ }^{356)}$. またこ れにより無機ガスの分析を行ない，酸素は $4.5 \times 10^{-10}$ $\mathrm{mol}$, 窒素は $2.7 \times 10^{-9} \mathrm{~mol}$ の微量が検出された ${ }^{35 \pi)}$. ${ }^{90} \mathrm{Sr}$ を線源と卉る検出器の試作 ${ }^{47}$, ${ }^{147} \mathrm{Pm}$ 孛線源とす る毛細管力ラム用の $5 \sim 7 \mathrm{~mm}^{3}$ の小容量検出器 ${ }^{113)}$, 放 射性同位元菜のかわりにヘりウム放電を電子供給源とし た補助放電アルゴン検出器 $393>394)$ ，自繶放電イオン化検 出器による無機ガスの分析105)199) などの研究がある.ア ルゴンの代わりに高純度へリウムを使用したものき3902， イオン化検出器におけるアルゴンとヘリウムの比较の研

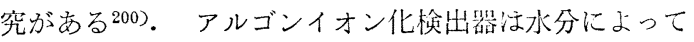
大きな影響をうけるが，簡単なバルブを市販 GCにとり つけて水分を除去し，感度を一定に保持する試み多京さ れた ${ }^{252)}$. Lovelock の二極型検出器において，ピーク 面積パーセントと試料の成分重量パーセントとの間には きわめてよい一致があった ${ }^{369)}$. 宗た，高沸点試料が検 出器内で㠜縮与るのを防ぐため，500○ C な゙の高温でも 使用できる検出器が報告されている1ひ).

クロスセクション型検出器法他のイオン化検出器に比 ベ，その応答が正確かつ感度と試料濃度との間に広い範 囲にわたって直線関係が成立与るという利点を有与る が，感度が低いという久点がある.この点を改良した比 較的簡単な構造の検出器が発表された ${ }^{240)}$. この型の検 出器法々の応答から試料の紿対濃度が求められることを 利用してステロイドのカラム中に括ける分解揁失舅の検

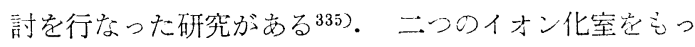
た小容量クロスセクション型検出器が無機ガス, 崖化水 素の分析に利用された4).

electron capture 型検出器電離箱領域のもっとも 低電圧で操作されるもので，その特長としては，ハロゲ ン，酸素など電気㓌性度の大きな原子定含む試料に対し ては, 現在のイオン化検出器中では最も大きな感度を有 一る。その選択性を利用することにより前記原子を含さ 極微量成分の検出が可能となった・ガソリン中のア゙ルキ 


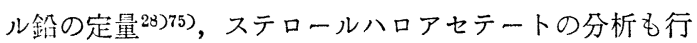
なわれ，モノクロルアセテートが最も感度が大であっ た225).この型の検出器に対する操作因子の研究が行な われ，電子に対する試料の親和力はヘテロアトムの電気 㓌性度だけでなく，試料分子の構造が関係し，枝分かれ した異性体は親和力が 增大することが確認された ${ }^{226)}$.

亡た, この型の検出器の異状応答に対する考察 ${ }^{240)}$, 電子 捕獲係数の測定, 理論的考察がなされた ${ }^{384)}$.

その活かのイオン化検出器として ${ }^{90} \mathrm{Sr}$ を線源として 使用し, 中央にグリッドを有しそれに平行な両端の電極 に交流電圧を印加し，中央グリッドをわずかに円に保つ ことにより，移動しやすい電子による電流を相殺し，移 動しにくい陰イオンを中央グリッドで放電させて検出す る陰イオン検出器 ${ }^{339)}$, イオン化検出器と質量分析器の併 用により定量定性分析を行なう $\mathrm{Q}-\mathrm{Q}$ 検出器 380 )などが ある・

以上のような高感度検出器の検量線測定や, 感度検討 のための極微量試料を注入する, 気体試料希釉装置の研 究が行なわ礼た112)357). 放射性物質のガスクロマトグラ フィーに関して,その流出物を加熱した酸化銅上で $\mathrm{CO}_{2}$, $\mathrm{H}_{2} \mathrm{O}$ にし, ${ }^{14} \mathrm{C},{ }^{3} \mathrm{H}$ を電離箱で測定する方法201)389), $300^{\circ} \mathrm{C}$ 程度の高温での放射能測定 ${ }^{410)}, \mathrm{CH}_{4}$ ガスをキャ リヤーガス, カウンティングガスの両方の目的に使用し た例233)がある。

簡単な放射性物質用ガスクロマトグラフ ${ }^{179)}$, 放射性同 位元素の検出に液体シンチレーションをガスクロマトグ ラフと組み合わせたもの175) などの報告がなされた。ま た新しい検出器として, ${ }^{85} \mathrm{Kr}$ キノールクラスレートと 気体無機酸化剂との反応で遊離した ${ }^{85} \mathrm{Kr}$ をガイガー計 数管で 計数することにより酸化剂の同定が可能であっ た148). 流出物の放射能測定の際の検出器の信号を一般 式で補正することにより $1 \%$ 以内の精度が得られた 270$)$.

$\mathbf{9} \cdot \mathbf{4} \cdot 3$ 非イオン化検出器 従来, 非イオン化検出器 としては熱伝導型検出器が代表的なものであった. 高感 度イオン化検出器が開発された今日でも, なおその重要 性注減少していない。操作が簡単であり, 安洒で安定性 もよいなど種々の特長を有している・しかしこの型の検 出器の研究は現在ではほとえどなされておらず, 異なっ た原理に基づく検出器が多数開発されている. 定量分析 を行なう際に検量線を求めたりピーク面積を出したりす る必要のない Brunel 質量分析器を検出器として用い 試料成分を直接絶対質量で出したり ${ }^{40)}$, 高速走查の質量 分析装置を利用したカラム流出物の連続分析 ${ }^{87}$ ), 飛行時 間型質量分析器を用いた同様の研究91)があるが，いずれ 微量成分の検出にも用いうるという利点がある・気体
密度天びえの理論と炭化水素, 芳香族, 䘏化物などの分 析への応用 ${ }^{271)}$, 市販の気体密度天びえの利用による検 出152) などの研究も報告されている。新しい形のものと して酸化亚鉛の半導性薄膜をボロシリケートガラスに真 空蒸着したものを用い, 試料が吸着すると電気伝導度が 変化することに基づいた検出の研究がなされた ${ }^{328) . ~ ま ~}$ た選択性のある検出器として，試料を燃焼しできたガス を水溶液に導入し, 電気抵抗が変化するととを利用した 検出法 ${ }^{293)}$ やプロセスガスクロマトグラフによる芳香族 の定量に 2375A のUV を用いた検出器 ${ }^{261)}$, 市販の接 触燃燒装置を利用し, 炭化水素, アルコールの混合物を 燃燒フィラメントの電流を適当に選択することにより後 者のみの検出が可能であり, 分離していないピークに対 しても適用される111). また, 通常誘電率の精密測定に 使用されるマイクロウェーブ回路を利用する方法 ${ }^{184)}$, 分 離された金属キレートを感度よく選択的に定性する手段 として炎光を利用したもの 187$)$, カラム流出物の定性にス ポットテストを応用した簡単な装置60)などの研究が報告 されている。

$\mathbf{9 \cdot 4 \cdot 4}$ リードアウトＬewin はガスクロマトグラ フ装置に関する解説の中でリードアウトにもふれてい る295).

自動的な感度切り換え装置の原理 ${ }^{155)}$, 階段的に行なう 感度切り換え装置の研究1)312257)が行なわれた. なた, 熱 伝導度型検出器用の簡単な連続的感度切り換え装置に関 する報文もある3 ${ }^{3}$. 自動積分器の研究も多数報告されて いて，ルーチン分析への適用を考えるときわめて有用で あると思われる・ピーク高さと保持容量との積を定量の 手段とする考えは従来から提案されていたが, 非常に簡 単な装置でその積を記録し，良好な結果が得られた ${ }^{203)}$. そのほか光学的方法による面積算出装置 ${ }^{383)}$, 折り返して ピークを記録し，スケールアウトしたりすることのない ようにしたり ${ }^{158)}$ ，自動的に積分值を印字したり ${ }^{163) ， テ ~}$ 一プに録音する方法8 など多数の提案がなされた。ま た，ガスクロマトグラフィーデータの保存や自動的な計 算についていくつかの研究が報告されている185)228)247).

\section{5 定性扔よび定量分析}

$9 \cdot 5 \cdot 1$ 定性分析 有機化合物の保持時間をその構造 と関係づけることは GC 定性分析において有効なことで あり，これに関する研究も少なくない・ステロイドの分 野でもこのような関係を求めることによって分離の際の 液相の選択の指針となり，生物体試料の未同定ステロイ ドの場合には構造の知見をうるに役立つ.ステロイけの 相対保持時間は次式のように示すことができる216). 


$$
\log \gamma=\Sigma \Delta \mathrm{R}_{\mathrm{Mg}}+\log \gamma_{\mathrm{N}}
$$

$\gamma_{N}$ ：ステロイド核の相対保持時間, $\Delta \mathrm{R}_{\mathrm{Mg}}$ ：核にグル ープ $(\mathrm{g})$ を導入した場合の $\log \gamma$ の变動であり， $\Delta \mathrm{R}_{\mathrm{Mg}}$ はペーパークロマトグラフの $\mathrm{R}_{\mathrm{f}}$ と同じクロマトグラフ 的意味を有する。 QF-1-0065 カラムを用いて分離した ステロイドについて種々の官能基の $\Delta \mathrm{R}_{\mathrm{Mg}}$ 值が測定さ

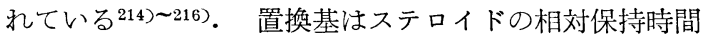
に影響する ${ }^{74)}$. この值はまた温度に依存する。

ステロイド数およびT值を用い，保持時間との関係を 調ベて保持值のデーターから未知ステロイドの構造を推 定した試みもある ${ }^{377)}$.

$\mathrm{R}_{\mathbf{x}_{9}}$ 法も引続き研究されている100) 103). この方法 ${ }^{336)}$ はまず，n-パラフィン 同族体のクロマトグラムを記録 乙，保持時間（R）の対数を炭素原子の数（N) に対し てプロットする．このグラフで直線が $\mathrm{N}=9$ 軸と交わる 点を標準保持時間（theoretical nonane）にとる。こ れと比較したパラフィン同族体の各化合物の保持時間は 次式で与えられる。

$$
\log R_{N_{9}}=\log R_{N}-\log R_{9}
$$

$\mathrm{R}_{\mathrm{N} 9}$ : 炭素数 $\mathrm{N}$ のパラフィンの保持時間, $\mathrm{R}_{9}$ : nonane の保持時間である. 次に未知物質とパラフィン同族体の 化合物の一つとの混合物のクロマトグラムを記録し次式 から未知物質の相対保持時間を求める。

$$
\mathrm{R}_{\mathrm{X} 9}=\mathrm{R}_{x_{\mathrm{N}}} \times \mathrm{R}_{\mathrm{N} 9}
$$

$\mathrm{R}_{x_{\mathrm{N}}}$ ：内標準と比較した未知物質の保持時間である. $\mathrm{R}_{\mathrm{N} 9}$ 值は適当なカラム温度では保持值の対数と炭素数の プロット（log プロット）から求められるが，高温では この方法は実際的でないため $\log$ プロットの傾斜から計 算する簡易な方法が発表された ${ }^{103)}$. 未知物質の $\mathrm{R}_{x \boldsymbol{9}}$ 值 は次式で計算できる.

$$
\mathrm{R}_{\mathrm{X} 9}=\mathrm{R}_{x_{\mathrm{N}}} \times 10^{\mathrm{b}(\mathrm{N}-9)}
$$

$\mathrm{b}: \log$ プロットの傾斜である.

新しい保持パラメーター $(\Delta \mathrm{Me})^{104)}$ が用いられた。 $\Delta \mathrm{Me}$ は溶質の有効分子量 $(\mathrm{Me})$ と真の分子量 $(\mathrm{M})$ の差で化学構造と保持值を関係ゔける有用なパラメータ 一である. Me は一般に次式で示すことができる.

$$
\mathrm{Me}=14.026 \frac{\log \mathrm{R}_{x_{\mathrm{N}}}}{\mathrm{b}}+\mathrm{M}_{\mathrm{N}}
$$

$\mathrm{R}_{x_{\mathrm{N}}}$ ：炭素原子 $\mathrm{N}$ の $n$-パラフィンについての保持比,

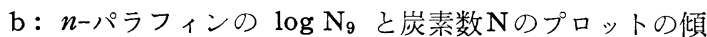
斜， $\mathrm{M}_{\mathrm{N}}$ ：分子量である. $\Delta \mathrm{Me}$ は限られた範囲内では 同族体については一定で温度と直線関係にある101)。周
期表の同じ族の置換基で $\Delta \mathrm{Me}$ は規則的に変化する.

相対保持時間注研究者によって相違する. 保持比の代 わりに Kováts 保持指数を用いると有機構造の確認に 有効で，この保持パラメーターを用いると極性液相につ いて多数の炭化水素の結果が厳密に比較でき, 装置や実 験条件に無関係である ${ }^{81)}$. Kováts 式は昇温操作の場合 にも当てはまるように変形され， SE-30 およびカーボ ワックス $20 \mathrm{M}$ カラムについて多数のエステル, アルコ ール，アルデヒド，ケトンの保持指数が発表された ${ }^{374) .}$ 直鎖パラフィンの沸点をとの炭素数の 100 倍に相当する よう目盛って沸点指標と定燨し, 保持指数との関連につ いて調ベた報告256)もある。

高沸点, 高分子量化合物の沸点と保持時間が計算でき る方法が研究され251)，極性の異なる2本のカラムについ て与えられた同族体化合物の定温保持容量の比あるいは 昇温保持容量の差が一定であることを利用して未知化合 物の官能基の同定が行なわれた ${ }^{259)}$. 揮発性有機化合物 の同定に液相として 4 種のものを充てんしたカラム 4 本 を用い, 試料を同時に流出させて一つの検知器で測定す る方法 ${ }^{409)}$ が研究された. 得られるクロマトグラムスペ クトルは各化合物について特長的で未知物質の同定に役 立つ.

揮発しにくい物質を熱分解し，その生成物を分離同定 する方法は GCの重要な分野で，有機化合物中のベンゼ

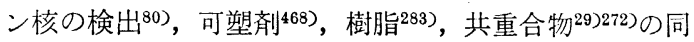
定についての研究がある. 熱分解の温度と試料量は生成 物の相対量に影響一-5る ${ }^{94)}$. 試料々う入装置 ${ }^{297)}$, 少量の試 料で再現性の得られる迅速熱分解装置67の考案もあり, 広範な 温度範囲で使用でき, 固体, 液体を問わず試料 とその残さが正確に測定できる熱分解装置も開発され た ${ }^{94)}$.

パラジウム，白金などの触媒を用いて水添し微量有機 化合物の炭素骨格および官能基の位置を決める方法 ${ }^{34}$ ) 興味深い。また, GC から流出した化合物を水素と炭酸 ガスに変え, 補助カラムで分離して両ガスのピーク面積 比から各物質の $\mathrm{H}: \mathrm{C}$ を連続的に求める方法がラベル 付化合物に用いられた ${ }^{57)} \mathrm{GC}$ と他の機器の併用は定性 分析で一般に採られるが，流出物を NMR で調べる研 究21198）があり，ミクロクーロメトリーと組み合わせて 塩素あるいはイオウを含む農薬類の相対保持データも求 められた46)。

化合物の保持データは $\mathrm{GC}$ 尃門誌に多数報告されてい るが， $\mathrm{C}_{2} \sim \mathrm{C}_{7}$ 範囲の飽和および不飽和炭化水素のいろ いろの固定相での相対保持データも発表された ${ }^{70) 337) . ~}$

$9 \cdot 5 \cdot 2$ 定量分析 熱伝導型検出器について気体分子 
運動論からモル応答係数を計算する方法が研究されてい る 169)241258). 炎イオン化検出器を用いた場合の種々の置 換有機化合物の相対レスポンスも研究され ${ }^{95)}$ ，高分子パ ラフィンおよびアルコール類の相対レスポンスを炭素数 に対してプロットすると両同族体の直線の傾斜は実験誤 差内で一致するが，アルコールのレスポンスは対応する パラフィンのそれより炭素数 $1 / 2$ だけ少ないものに相当 する287). halothane その他数種の化合物ではピーク面 積と濃度の間には対数的な関係があるが，カラム温度あ るいはへリウム流速を下げると溶質 $1 \mu l$ までは直線関 係が得られる68). 直線からの偏倚の原因は検出器の過重 によるという．炎イオン化検出器を用いる連続昇温 GC ではカラムを通しての圧力降下を昇温操作中一定に保つ と再現性のよい正確度の高い結果が得られる ${ }^{99)}$. electron capture 検出器の温度, 流速, 加電生などの变動 の影響が sec-臭化ブチルについて定量的に検討され， 加電圧源に直流電源を用いる場合には検出器温度を高く して流速をさげると好結果が得られ，パルス加電圧で は検出器温度が 高いと感度が低下することが 報告され た226).

脂肪酸メチルエステルの相対的レスポンスと酸の炭素 数之の関係が検討され，種々の同族体について相対モ ルレスポンスと炭菜数は比例関係にあることが示され

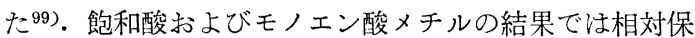
持容量の対数と分子量淔線関係にあるが，不飽和二重 結合数との間には直線関係がない177)。 ピーク面積を応 答係数で割った “ reduced peak area”という值を 用いると脂肪酸の正確な定量分析が可能になる ${ }^{188}$. 脂 肪酸のメチルエステル化法としてヨウ化メチルを酸の銀 塩と反応させる方法は副反応が起らず，揮発性なエステ ルの損失もない125). 担体の状態も結果に影響するが， ケイソウ土は酸あるいはアルカリ処理を, 耐火れんがは hexamethyldisilazane あるいはラウリン酸ナトリウム で前処理すると吸着も起らず，脂肪酸メチルエステルの 対称性のよいピークが得られる ${ }^{53)}$.

検量線を用いないで定量分析する方法として GCで分 䧸した有機物を燃焼して炭酸ガスに变え，アミノエタノ ールのピリジン溶液に吸収させ，ナトリウムメチレート で滴定する方法も提案された ${ }^{42}$.

金属有機錯体を GCの対象とした研究も盛えになり， アセチルアセトン, トリフルオロアセチルアセトン，ヘ キサフルオロアセチルアセトンの金属錯体を GCで定量 分析する研究が行なわれた 115)168)3123333). 光学的異性体 あるい戥何学異性体の分離も可能であり $\left.{ }^{332} 3333\right)$, 検出 器に炎光光度法を用いるとピークが重なる金属錯体を定
量する場合に便利である187).

水溶液中の塩素イオン, 臭素イオンに硫酸を加えて掹 化水素, 臭化水素に変え, GC で定量する方法も研究さ れた ${ }^{37) . ~}$

\section{$9 \cdot 6$ 特 殊 使 用}

$9 \cdot 6 \cdot 1$ 分取ガスクロマトグラフィー GC は蒸留法 などに比べてその分離能がすぐれているが，通常の GC で取り扱う試料の量は一般にわずかである. そのため純 物質を調製したり，IR，NMRなどによる分析試料を採 取するには不適当な場合が多いそこで，これらの目的 のため多量の試料を分離することのできる分取ガスクロ マトグラフの研究およびその使用が近年盛んに行なわれ

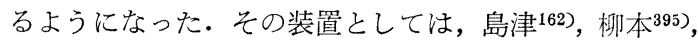
Wilken ${ }^{61) 82)}$, Nester/Faust ${ }^{62)}, \mathrm{F}$ and $\mathrm{M}^{303)}$ など自 動的に分取できる市販品の紹介をはじめ, 各装置の比 較 ${ }^{254)}$, その設計上の問題点 ${ }^{353)}$, 特に加熱装置 ${ }^{172)}$, 試料 気化室 ${ }^{211)}$, トラップなど良好な分離を得るための条件に ついて検討され，設計試作が行なわれている6)354)363). 分取 GCでは一般に大口径カラムを用いて試料の処理能 力を増加させているが, カラム中におけるガスの流速, 液相および温度分布の不均一性などのためにその効率が 低下する.これらの点を改良する目的で種々の考案がな され, カラムの内壁に液相をつけたり ${ }^{353)}$, カラム芠環状 にしたり ${ }^{62)}$ ，小口径カラムを多数本併列にしたり，カラ ム内部にひだをつけてカラム内部を細分化したり ${ }^{392)}$ ，ま た軸しえを入れたりしている211). カラムへの固定相担 体の良好な充てえ方法としては, 窒素気流で流入させた り ${ }^{151)}$, 電磁的振動によって均一につめ, さらに液相を流 入させる方法 ${ }^{32}$ などが考えられている. 分取 $\mathrm{GC}$ でのカ ラムの径と担体の粒子径の比は $25: 1$ 程度が分離効率の 点でよいといわれる38).小口径の分析用カラムを用いて， 比較的多量の試料を分取するときのカラムのオーバロー ドは流速によってカバーすることもできる326). また多 数本で一組のカラムを用い, 複雑な混合物中特に速く流 出する成分と, 抢そく流出与る成分をカットし, 目的と する成分のみを効果的に分取する再循環型の流路方式の 提案144)な゙分取 GC の改良がなされている. 分取 GC の理論的な取り扱いもなされており136)137)139), 各種条 件のカラム効率に及ぼす影響が考察されている. 分取 GC における試料の 1 回の注入量は数グラムから特に大 口径カラムでは $500 \mathrm{~g}$ 程度のものが報告され32), 分取 GC は各種の混合物の分離に応用される。

$9 \cdot 6 \cdot 2$ 連続分取法 分取 GCで混合物の分離を連続 的に行なう研究も報告されている. その例として, 直径 
$6 \mathrm{~mm}$, 長さ $1.2 \mathrm{~m}$ のカラム 100 本を一組としてドラム 状に配列し, キャリヤーガスを全部のカラムに一様に通 じながら，そのカラムのドラムを 1〜50 回転/時間の一 定速度で回転させる方法が提案されている ${ }^{83) 294) . ~}$ は上部の同一位置でつぎつぎに注入され, 分離された成 分は下部に用意された同じ位置のトラップに連繶的に捕 集される。このような方法でベンゼンとシクロヘササン の混合物を $180 \mathrm{ml} / \mathrm{hr}$ の速さでそれぞれ $99.9 \%$ 以上 の純度で分取することができる．またこれと類似の方法 で, F and M 社で活62) 121 本のカラムを用いて，金 属ホウ素の製造の中間物のペンタボランの精製用連続 GC 学試作している。このような回転するカラムドラム の方式とは別に, 固定相担体層を流動させる Movingbed GC の提案もある. そしてエーテル, ジクロルメタ ン，ジメキシメタンの混合物をこの方法によって二つ の成分に連続的に分取方る試みがなされている110)。流 下する液相中をガス流ぶ水平方向に移動するような方 法，すなわち，薄層クロマトグラフィーと GCを組夕合 わせて連続的に分離する方法 ${ }^{370)}$ などの考案もある. 回 転連続 GC の理論的取り扱いについての報告126)もあり， この装置が大口径カラムよりも良好な分離が得られ, 最 適条件の選択に及ぼす各因子について検討されている.

\section{$9 \cdot 6 \cdot 3$ 昇温ガスクロマトグラフィー（PTGC） よ}

り広範用の沸点成分を能率的に分離, 分析するための手 段としての PTGC は多くの有用性をもっており，乙れ らに関子る研究も多数行なわれている. 寒剤温度 $(-65$ ${ }^{\circ}$ C) 範囲だの PTGC ${ }^{260)}$, 熱空気による能率的な温度制 御172)，クロマトサーモグラフィー280)，昇温ではなくて 温度を下降させながら行なう方法による $\mathrm{C}_{2} \sim \mathrm{C}_{6}$ 炭化 水素の効果的な分析方法 ${ }^{368)}$, など加熱の方法および温 度範囲の選択などによっておこるその特性を利用した PTGC の研究が行なわ机ている. 高感度検出器をもつ PTGC でのベースラインのドリフトの preconditioning による除去 ${ }^{223)}$, ダブルカラム方式による揮発性液 相に起因する信号の補償93)などもみられる。 PTGC に おける保持時間と保持温度の変動は後者のほうが温度上 昇速度の変化に対して少ないことが示されている249. PTGC の実際分析への応用例としては，炭化水素およ び脂肪酸エステルの定量 ${ }^{99)}, \mathrm{C}_{6} \sim \mathrm{C}_{26}$ の広い範囲のアル コール類, アルカン, アルケンの定量 273$), 8$ 種類の二ト ロパラフィンの分析 ${ }^{39)}$, 希薄溶液中の高沸点微量成分の 走量 ${ }^{209) な と ゙ か ゙ あ け ゙ ら れ る 。 ま た ， c i s ~ お よ ひ ゙ ~ t r a n s の ~}$ デカリンの分取 GC への適用 ${ }^{392}$ 市ども示されている. PTGC の理論についての報告もみられる135)154)313).

9.6 .4 微量分析 GC によって特に微量の成分を分
析することは以前からも研究されているが，最近注高感 度検出器の進歩とともにさらにその利用が拡張されてい る・たとえば，大気またはエンジン排父ガス中の $\mathrm{ppb}$ オーダー濃度の炭化水染(6)17333), 互硫酸ガス16)の定量が 大気污染の問題に関連して研究された。これらは液体窒 素交たは液体酸素の温度で，これら成分をあらかじ心捕 集，濃縮する手段がとられ，高い捕集率を得るような装 置が考案されている. 金属材料中の微量炭素 $\left.{ }^{242}\right)$, 等素, 水素, 酸䋕20233450定量に GCの忘用が行なるれるよう に㾂り，往来の金属中のガス分析法に比して簡䍩化さ

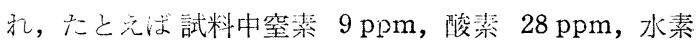
$0.2 \mathrm{ppm}$ 程度の微量が定量されている ${ }^{344)}$. 各種有機物 微量成分への GCの適月も多数市り,たとえば各種アる ノ酸を electron affinity 検出器を朋いる GCによっ て $(3.12 \pm 0.41) \times 10^{-16} \mathrm{~mol} / \mathrm{sec}$ の感度で定量してい る227. 微量のガスサンブラーの設計も研究され, その 容量 $140 \mu l$ のものを用いて筀素中 $\mathrm{C}_{1} \sim \mathrm{C}_{4}$ 炭化水素の $100 \sim 200 \mathrm{ppm}$ を含を試料を分析し，各ピーク高の平均 偏差が士0.5\% よりも良好なものが作られている246). 溶媒中の低沸点の微量成分, たとえば $100 \mathrm{ml}$ 程度のア セトン中のミリグラム程度のエチレンオキサイド（沸点 $13^{\circ} \mathrm{C}$ ) を PCVR head を用いて能率良く蒸留濃縮する 方法が提案され(10)，GC による微量成分分析への応用が 考慮されている。

9.6.5 工程管理分析 GC を工場の工程管理分析に 使用することは, 石油化学の分野などにおいて著しい効 果がある.たとえばプロパン分留工場において，モニタ 一用の GC 学設置することによってプロパンの収率が 10\% 上昇した ${ }^{281)}$. また, 石油精製工程の動的变化を $\mathrm{GC}$ によって知ることができ, たとえば $i-\mathrm{C}_{4}, n-\mathrm{C}_{4}$ 炭化水 素の分留の場合，相互に 8～10\%の混入堂生じていたも のが，GC によるコントロールて 0.5\% 以下の混入にま でさげることを可能としている371)。紫外線吸収検出器 をつけた工程管理用 GC が開発され, 複雑な混合物の完 全な分離它寸ることなく, 芳香族成分の直接定量它可能 にし，実際の精製工程におけるガス流中のベンゼンおよ びトルエンの定量に適用されている261). そのほか, 水 中に溶解しているガス成分を流路の途中で多段回転久ト リッパー类用いて水から分離し， GCによって分析した り ${ }^{388)}$, 原子力二業において工程の流れに含まれる六フッ 化ウラン, 三フッ化塩素, 䘏素, フッ化水素京よびその 他の化学反応性に富えだフッ化物混合成分の GCによる 自動分析法が開発されている159). このような高反応性 フッ化物混合成分への GLCには特別な装置とテクニッ クぶ必要であり, 液相にはポリトリフルオロモノクロロ 
エチレン (Kel-F) が使用されている.そのほか，自動 GC に用いる自動的ガス試料採取装置の開発なども行な 称て ${ }^{59)}$ ，工程管理用 GCの改良㔔なされている。

\section{$9 \cdot 7$ の 他}

GC を無機化学方面に灾用した報文は最近かなり多く なっている.揮発性舤気八ラ今ド化合物の分析159)277)314),

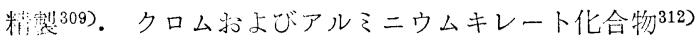
332)，ケイ素，ゲルマニウムの揮発性水素化物38)282)292), 四エチル鉛など揮発性付機金属化合物45)の分析，金属中 のガス分析 ${ }^{202}$ 344)，岢るいはシクロペンタジエンナトり ウムと遷移金属八ライド錯化合物との反応 ${ }^{333)}$, スカンジ ウムのアセチルアセトン錯化合物 ${ }^{115)}$ ，マンガン酸化物と 酸素の高温での挙動352)などの研究がある.

脂肪酸の分析はエステルの形で行なわれており，ジエ チレングリコールコハク酸ポリエステル艺固定相とした 湤:産動物油の脂肪酸121)，2段 GC による低位カルボン 酸 ${ }^{189)}$ ，ムクロジ種子油の脂肪酸330), 米ヌカ油の脂肪 酸266) の定量, 水掏炎イオン化検出器による污濁水中の 低級脂肪酸の $0.01 \%$ までの定量 ${ }^{234)}$ ，ナタネ涔中の不飽 和酸の酸化過程の研究360)などがある.

$1 \%$ N. G. S.（既出）空液相に用いて各種ア之ノ酸の n-ブチル-N トリフルオロアセチル化物がメチルエステ ルの形で㐓踓され407)，たと光ば，22 琵の天然アミノ酸 混合物は 42 分で分析文几た。

高分子関係の報文も心なり增えている。层素樹脂400 401), メチロールメラミン樹脂396), サリゲニン397, $p$-メ チロールフェノール393) などの合成樹脂の熱硬化反応 機構の解明のため, 初期反応生成物次ら生引゙るガス状 物質が GC で分析された。砂糖ふよびその関連物質は 3\%SE-52，10\% カーボワックス 1540，または 15\%エ チレングリコールコハク酸ポリエステルを固定液相とし てトリメチルシリル化物の形で346), マンニトールとソル ビトール洨ヘキサアセチル化物として ${ }^{164)}$ ，メチルグリコ サイドはブタン-1, 4-ジオールコハク酸ボリエステル芯 液相沉して22)それぞれ分離定量された。

医藻品関係の応用例としては，医薬品製剂少よび食品 に添加使用される保存剂176), 殺虫刘 DDVP(195), 除草剂 2,4-Dエチルエステル ${ }^{196)}$. ビタミンA油中の $\mathrm{BHT}{ }^{194),}$

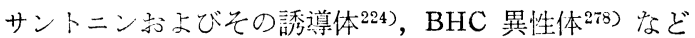
の分所が報告されている。この活か 2 年間の国内交献の おも㐫もの湖のとおりである・アルキルベンゼンスル ホン酸ナトリウみと PEG $=6000$ の $1: 1$ 混合物を液相 としたメントール颣の分析 ${ }^{3(4)}$, 含酸素テルペン化合物お よざ香料成分の液相の選护 ${ }^{20}$ ，クスノキ科植物精油成分
の分離 ${ }^{279)}$ ，ヒノキ葉ろう中のアルカン類の検出 ${ }^{120)}$, ア ルカロイド類の熱分解による同定定量2203221)404)，ベンゼ ン類学含さフェノール類の定量 ${ }^{372)}, 2,4-\mathrm{D}, \mathrm{N}-$ フェニル ヒドラゾンの熱分解によるカルボニル化合物の分析275),

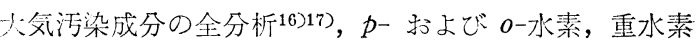

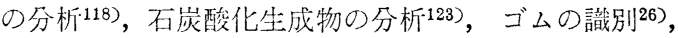
$\alpha$ および $\delta$-シクロゲラニオレンの分析14などである.

$\mathrm{GC}$ の分析以外への応用も最近活発に告っており，既 述のもの以外に次の研究が報告されている. 気液分配係 数の測定 ${ }^{27) 56)}$. 気液境界面での溶質の吸着 ${ }^{253)}$, 界面活性 剂の比極性の測定 ${ }^{170)}$, 炭化水素のポリハロゲン化物とル イス塩基との分子間相互作用 ${ }^{402)}$, 有機化合物の気液相分

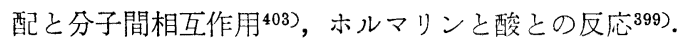

\section{交献}

1) H. Abegg: J. Chromatog., 9, 405 ('62); 2) H. Abegg: ibid., 9, 519 ('62); 3) K. Abel, W. B. Dabney: Anal. Chem., 35, 1335 ('63); 4) K. Abel, H. deSchmertzing: ibid., 35, 1754 ('63); 5) R. F. Abernathy, T. Christos: ibid., 35 (5), 78R ('63); 6) R.G. Ackman, M.A. Bannerman, F. A. Vandenheuvel: J. Chromatog., 8, 44 ('62); 7) R. G. Ackman, F. A. Vandenheuvel: Chem. Can., 15 (2), 34 ('63); 8) L. M. Addiison, L. H. Lane: Z. Anal. Chem., 189, 80 ('62); 9) E. R. Adlard, B. T. Whitmam: Nature, 192, 966 ('61); 10) N. Adler: Anal. Chem., 35, 724 ('63).

11) D. Ambrose: Nature, 194, 824 ('62); 12) D. Ambrose, B. Ambrose: "Gas Chromatography"', ('62), (Van Nostrand, Princetion, N. J.); 13) H. P. Argele, H. G. Struppe, ed.: "Gas-Chromatographie, 1963 ", 421pp. ('63), (Akademie-Verlage G. m. b. H., Berlin); 14) A. Arai, C. C. Yao, I. Ichikizaki: Bull. Chem. Soc. Japan, 36, 1432 ('63) ; 15) 荒木 晙, 加藤竜夫: 分化，12，179 ('63); 16) 荒术 峻, 加藤竜夫：同 上, 11, 533 ('62); 17) 荒木 峻, 加藤竜夫：同上, 12，1027（'63)；18）荒木 峻, 加藤竜夫：化学の領 域増刊号, ガスクロマトグラフィー第 3 集, p. $72\left({ }^{\prime} 62\right)$, (南江堂); 19) 荒木 峻, 加藤竜夫, 跡部輝产: 分 化，12，450（'63）；20）荒谷孝昭, 古前 恒, 松浦 多聞：工化，65，1565 ('62).

21) E. D. Archer, J. H. Schiverly, S. A. Francis: Anal. Chem., 35, 1369 ('63); 22) G. O. Aspinall: J. Chem. Soc., 1963, 1676; 23) H. J. Ast: Anal. Chem., 35, 1764 ('63); 24) E. P. Atkinson, G. A. P. Tuey: Nature, 199, 482 ('63); 25) W. Averill: J. Gas Chromatog., 1 (1), 22 ('63)；26） 馬場 孝，徳丸章二：ゴム協，35，163 ('62) ; 27) P. E. Barker, D. I. Lloyd: J. Inst. Petrol., 49, 73 ('63); 28) E. M. Barrall, II, P. R. Ballinger: J. Gas Chromatog., 1 (8), 7 ('63); 29) E. M. Barrall, II, R. S. Porter, J. F. Johnson: Anal. Chem., 35, 73 ('63); 30) E. H.

Baum: J. Gas Chromatog., 1 (11), 13 ('63).

31) F. Baumann, F. A. White, J. F. Johnson: 
Anal. Chem., 34, 1351 ('62); 32) E. Bayer, K. P. Hupe, H. Mack: ibid., 35, 492 ('63) ; 33) T. A. Bellar, M. F. Brown, J. E. Sigsby: ibid., 35, 1924 ('63); 34) M. Beroza: ibid., 34, 1801 ('62); 35) M. Beroza: Nature, 196, 768 ('62); 36) M. Beroza, R. Sarmiento: Anal. Chem., 35, 1353 ('63); 37) L. G. Bergmann, R. L. Martin: ibid., 34, 911 ('62); 38) R. M. Bethea: J. Chromatog., 8, 21 ('62); 39) R. M. Bethea, F. S. Adams: ibid., 8, $532\left({ }^{\prime} 62\right)$; 40) S. C. Bevan, S. Thorburn: ibid., 11, 301 ('63).

41) C. T. Bishop: "Methods of Biochemical Analysis ", David Glick, ed., Vol. X, p. 1 ('62), (Interscience, New York); 42) L. Blom, L. Edelhausen, T. Smeets: Z. Anal. Chem., 189, 91 ('62) ; 43) K. J. Bombaugh: J. Chromatog., 11, 27 ('63) ; 44) K. J. Bombaugh: Nature, 197, 1102 ('63); 45) E. J. Bonelli, H. Hartmann: Anal. Chem., 35, 1980 ('63); 46) W. A. Bosin: ibid., 35, 833 ('63); 47) H. K. Bothe: Nuc1. Sci. Abstr., 15, 3978 ('61); 48) N. Brenner, J. E. Callen, M. D. Weiss, ed.: "Gas Chromatography", 719pp. ('62), (Academic Press, New York); 49) E. Brochmann-Hanssen: J. Pharm. Sci., 51, 1017 ('62); 50) I. Brown: J. Chromatog., 10, 284 ('63).

51) W. B. Brownell, F. E. Chadde, J. G. Theivagt, D. C. Wimer: Anal. Chem., 35 (5), 143R ('63); 52) C. Brunnée, L. Jenckel, K. Kronenberger: Z. Anal. Chem., 197, 42 ('63); 53) H. Bürhing: J. Chromatog., 11, 452 ('63); 54) H. P. Burchfield, E. E. Storrs: "Biochemical Applications of Gas Chromatography ", ('62), (Academic Press, New York); 55) S. P. Burg: "Moderne Methoden der Pflanzenanalyse", Vol. V, H. F. Linskens and M. V. Tracey, ed., p. 97 ('62), (Springer-Verlag, Berlin); 56) M. G. Burnett: Anal. Chem., 35, 1567 ('63); 57) F. Cacace, R. Cipollini, G. Perez: ibid., 35, 1348 ('63); 58) H. V. Carter: Nature, 197, 684 ('63); 59) K. Casey, F. H. C. Edgecombe, D. A. Jarine: Analyst, 87, 835 ('62); 60) B. Casu, L. Cavallotti: Anal. Chem., 34, 1514 ('62).

61) Chem. Eng. News, 40 (14), 73 ('62); 62) ibid., 40 (37), 74 ('62); 63) P. Chovin: "Comprehensive Biochemistry ", Vo. 4, Marcel Florkin and E. H. Stotz, ed., p. 218 ('62), (Elsevier, New York); 7, $433(' 62)$; 681 ('63); 64) I. J. Clark: J. Chromatog., A. P. Altshuller: Anal. Chem., 35, 1546 ('63); 67) J. A. Cogliano: Rev. Sci. Inst., 34, 439 ('63); 68) E. N. Cohen, E. Parzen, D. M. Bailey: J. Gas Chromatog., 1 (8), 14 ('63); 69) E. R. Colson: Anal. Chem., 35, 1111 ('63); 70) S. M. Csicsery, H. Pines: J. Chromatog., 9, 34 ('62).

71) S. Dal Nogare, J. Chiu: Anal. Chem., 34, 890 ('62); 72) S. Dal Nogare, R. S. Juvet, Jr.: "Gas-Liquid Chromatography. Theory and Practice", ('62), (Interscience, New YorkLondon); 73) N. W. R. Daniels: Chem. Ind. (London), 1963, 1078; 74) D. Darlington, B.
A. Knights, G. H. Thomas: J. Gas Chromatog., 1 (6), 21 ('63); 75) H. J. Dawson, Jr.: Anal. Chem., 35, 542 ('63); 76) E. A. Day, P. H. Miller: ibid., 34, 869 ('62); 77) D. D. DeFord, R. J. Loyd, B. O. Ayers: ibid., 35, 429 ('63); 78) D. H. Desty, A. Goldup, G. R. Luckhurst, W. T. Swanton: "Gas Chromatography, 1962", M. van Sway, ed., p. 67 ('62), (Butterworths, London); 79) R. A. Dewar, V. E. Maier: J. Chromatog., 11, 295 ('63); 80) J. H. Dhont: Nature, 192, 747 ('61).

81) J. H. Dhont: Nature, 198, 990 ('63); 82) K. P. Dimick, E. M. Taft: J. Gas Chromatog., 1 (3), 7 ('63); 83) D. Dinelli, S. Polezzo, M. Taramasso: J. Chromatog., 7, 477 ('62); 84) H. B. F. Dixon: ibid., 7, 467 ('62); 85) T. Doran, A. D. Sperrin: Analyst, 88, 738 ('63); 86) K. Dorfner: Brennstoff-Chem., 43, 110('62); 87) J. A. Dorsey, R. H. Hunt, M. J. O'Neal: Anal. Chem., 35, 511 ('63); 88) J. E. Drake, W. L. Jolly: J. Chem. Soc., 1962, 2807; 89) C. M. Drew, J. H. Johnson: J. Chromatog., 9, 264 ('62); 90) J. L. Duffield, L. B. Rogers: Anal. Chem., 34, 1193 ('63).

91) A. A. Ebert, Jr.: Anal. Chem., 33, 1865 ('61); 92) C. P. Ellis: ibid., 35, 1327 ('63); 93) E. M. Emery, W. E. Koerner: ibid., 34, 1196 ('62); 94) K. Ettre, P. F. Váradi: ibid., 35, 69 ('63); 95) L. S. Ettre: J. Chromatog., 8, 525 ('62); 96) L. S. Ettre: ibid., 11, 267 ('63); 97) L. S. Ettre: J. Gas Chromatog., 1 (2), 36 ('63); 98) L. S. Ettre, E. W. Cieplinski, W. Averill: ibid., 1 (2), 7 ('63); 99) L. S. Ettre, F. J. Kabot: Anal. Chem., 34, 1431 ('62); 100) M. B. Evans: J. Chromatog., 12, 2 ('63).

101) M.B. Evans, J. F. Smith: J. Chromatog., 8, 303 ('62); 102) M. B. Evans, J. F. Smith: ibil., 8, 541 ('62); 103) M. B. Evans, J. F. Smith: ibid., 9, 147 ('62); 104) M. B. Evans, J. F. Smith: Nature, 190, 905 ('61); 105) E. Evrard, M. Thevelin, J. V. Joossens: ibid., 193, 59 ('62); 106) F. Farre-Rius, J. Henniker, G. Guiochon: ibid., 196, 63 ('62); 107) P. Fajes, J. Engelhardt, G. Schay: J. Chromatog., 11, 151 ('63) ; 108) P. Fajes, E. Fromm-Czárán: "GasChromatographie, 1961", Proc. 3rd Symp. on Gas Chromatog., p. 18 (Schkopau, East Germany, May 16-19 ('61); 109) E. R. Fett: Anal. Chem., 35, 419 ('63); 110) G. R. Fitch, M. E. Probert, P. F. Tiley: J. Chem. Soc., 1962, 4875.

111) O.F. Folmer, Jr., K. Yang, G. Perkins, Jr.: Anal. Chem., 35, 454 ('63); 112) I. A. Fowlis, R. P. W. Scott: J. Chromatog., 11, 1 ('63); 113) Y. A. Frank, M. I. Yanovskii: Nucl. Sci. Abstr., 15, 3979 ('61); 114) G. J. Frisone: Nature, 193，370 ('62); 115) 藤永太一 郎, 桑本 融, 小野祐資：分化，12，1199 ('63)；116)

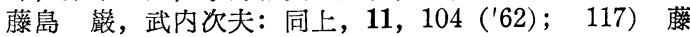
島 䮉, 武内次夫：工化，65，835 ('62)；118) 藤田 勝義，管 孝男：分化，12，15('63); 119) 福井清 史，永富英男，村田三郎：同上，11，432 ('62)；120) 福井義雄, 有吉晴美: 薬誌, 83, 1106 ('63).

121）福住一雄, 尹東祐隆：工化, 65, 1963 ('62); 
122）船久保英一，永井利一：同上，64，1438 ('61); 123）舟阪 渡, 小島次雄，木本実美：分化，12，247 ('63); 124) J. E. Funk, G. Houghton: J. Chromatog., 6, 281 ('61); 125) C. W. Gehrke, D. F. Goerlitz: Anal. Chem., 35, 76 ('63); 126) J. C. Giddings: ibid., 34, 37 ('62); 127) J. C. Giddings: ibid., 34, 314 ('62); 128) J. C. Giddings: ibid., 34, 458 ('62); 129) J. C. Giddings: ibid., 34, 722 ('62); 130) J. C. Giddings: ibid., 34, 1186 ('62).

131) J. C. Giddings: Anal. Chem., 35, 353 ('63) ; 132) J. C. Giddings: ibid., 35, 439 ('63); 133) J. C. Giddings: ibid., 35, 1338 ('63); 134) J. C. Giddings: Anal. Chim. Acta, 27, 207 ('62); 135) J. C. Giddings: J. Chem. Educ., 39, 569 ('62); 136) J. C. Giddings: J. Gas Chromatog., 1, (1), 12 ('63); 137) J. C. Giddings: ibid., 1, (4), 38 ('63); 138) J. C. Giddings: Nature, 191, 1291 ('61); 139) J. C. Giddings, E. N. Fuller: J. Chromatog., 7, 255 ('62); 140) J. C. Giddings, K. L. Mallik, M. Eikelberger: Anal. Chem., 34, 1026 ('62).

141) J. C. Giddings, R. A. Robinson: Anal. Chem., 34, 885 ('62); 142) L. Gildenberg, J. R. Trowbridge: J. Am. Oil Chemists Soc., 40, (9), 23 ('63); 143) M. J. E. Golay: Nature, 199, 370 ('63); 144) M. J. E. Golay, H. I. Hill, S. D. Norem: Anal. Chem., 35, 488 ('63); 145) H. J. Gold: ibid., 34, 174 ('62); 146) S. M. Gordon, G.J. Krige, P.C. Haarhoff, V. Pretorius: ibid., 35, 1537 ('63); 147) J. G. Grasseli, M. K. Snavely: Appl. Spectry., 16, 190 ('62); 148) B. J. Gudzinowicz, W. R. Smith: Anal. Chem., 35, 465 ('63); 149) E. Guenther, K. Kulka, J. A. Rogers, Jr.: ibid., 35, (5), 39R ('63); 150) G. Guichon: ibid., 35, 399 ('63).

151) C. L. Guillemin: J. Chromatog., 12, 163 ('63); 152) C. L. Guillemin, M. F. Auricourt: J. Gas Chromatog., 1, (10), 24 ('63); 153) H. W. Habgood: Ann. Rev. Phys. Chem., 13, 259 ('62); 154) H. W. Habgood, W. E. Harris: Anal. Chem., 34, 882('62); 155) H. Hachenberg, M. Junghanns, H. Reiniger: Brennstoff-Chem., 43, 225 ('62); 156) I. Halász, C. Horvath: Anal. Chem., 35, 499 ('63); 157) I. Halász, C. Horvath: Nature, 197, 71 ('63); 158) L. H. Hamilton: Anal. Chem., 34, 445 ('62); 159) A. G. Hamlin, G. Iveson, T. R. Phillips: ibid., 35, 2037 ('63); 160) W. W. Hanneman: J. Gas Chromatog., 1, (12), 18 ('63).

161）春木達郎：分化, 10, 1244 ('61)；162）春 木達郎：化学の領域増刊, 49, 134 ('62); 163) 春木 達郎, 藤原修壮：分化, 11, 38 ('62); 164) J. A. Hause, J.A. Hubicki, G.G. Hazen: Anal. Chem., 34, 1567 ('62); 165) G. S. F. Hazeldean, R. P. W. Scott: J. Inst. Petrol., 48, 380 ('62); 166) J. Herling, J. Schabtai, E. Gil-Av: J. Chromatog., 8, 349 ('62); 167) C. K. Hersh: "Molecular Sieves ", ('61), (Reinhold Publishing Co., New York); 168) R. D. Hill, H. Gesser: J. Gas Chromatog., 1, (10), 11 ('63); 169) E. G. Hoffman: Anal. Chem., 34, 1216 ('62); 170) V. R. Huebner: ibid., 34, 488 ('62).
171) G. L. K. Hunter: J. Chromatog., 11, 124 ('63); 172) G. L. K. Hunter, M. K. Veldhuis: ibid., 11, 11 ('63); 173) I. R. Hunter: ibid., 7, 288 ('62); 174) R. A. Hurrell, S. G. Perry: Nature, 196, 571 ('62); 175) F. A. Iddings, J. T. Wade: J. Gas Chromatog., 1, (1), 31 ('63); 176) 井口定男, 山本孫兵衛, 青山敏信: 薬 誌, 83, 721 ('63); 177) 伊東祐隆, 福住一雄: 工 化, 65, 1963 ('62); 178) R. M. Iyer, J. P. Mittal: J. Chromatog., 11, 404 ('63); 179) A. T. James, E. A. Piper: Anal. Chem., 35, 515 ('63); 180) J. Jaroslav: J. Gas Chromatog., 1, (4), 6 ('63).

181) P. Jenkins: Nature, 197, $72(' 62)$; 182) D. Jentzsch, W. Hövermann: J. Chromatog., 11, 440('63); 183) J. Gas Chromatog., 1718 Sherman Ave., Evanston III.; 184) G. Johanson: Anal. Chem., 34, 914 ('62); 185) H.W. Johnson, Jr.: ibid., 35, 521 ('63); 186) R. S. Juvet, Jr., S. Dal Nogare: ibid., 36, (5), 36R ('64); 187) R. S. Juvet, Jr., R. P. Durbin: J. Gas Chromatog., 1, (12), 14 ('63); 188) F.J. Kabot, L.S. Ettre: ibid., 1, (10), 7 ('63); 189) 鏑木陽一：日化, 83, 1035 ('62); 190) 化学の領域増刊, 第 3 集, ('62), (南江堂).

191）化学の領域増刊, 第 4 集, ('62), (南江堂); 192) 同上, 第 5 集, ('63), (南江堂); 193) R.

Kaiser: "Gas Chromatography", Vol. I,' Capillary Chromatography", Vol. II, “Tables for Gas Chromatography', Vol. III, ('63), (Butterworths, Inc., Washington); 194) 神尾英雄, 島 高：分化, 11, 731 ('62); 195) 金沢 純, 佐藤六郎： 同上，11，122 ('62)；196) 金沢 純，佐藤六郎：同 上, 11，523 ('62); 197) 神原富民: 化学の領域増刊 号, ガスクロマトグラフィー第 3 集, p. 29 ('62), (南 江堂); 198) 神林うた子, 額田健吉, 鈴木昭夫, 竹田 一郎, 富田 弘, 益子洋一郎: 工化, 66, 198 ('63); 199) A. Karmen, R. L. Bowman: Nature, 196, 62 ('62); 200) A. Karmen, L. Giuffrida, R. L.

Bowman: J. Chromatog., 9, 13 ('62).

201) A. Karmen, I. McCaffrey, J. W. Winkelman, R. L. Bowman: Anal. Chem., 35, 536 ('63); 202) 鹿島次郎, 山崎卓雄: 分化, 12, 347

('63); 203) G. Kateman: J. Chromatog., 8, 280

('62); 204) R. A. Keller, R. Bate, B. Costa, P. Forman: ibid., 8, 157 ('62); 205) R. A. Keller, G. H. Stewart: Anal. Chem., 34, 1834 ('62); 206) M. A. Khan: "Gas Chromatography, 1962 ", M. van Swaay, ed., p. 3 ('62), (Butterworths, London); 207) R. Kieselbach: Anal. Chem., 35, 1342 ('63); 208) G. R. Kingsley: ibid., 35 (5), 11R ('63); 209) J. J. Kirkland: ibid., 34, 428 ('62); 210) J. J. Kirkland: ibid., 35, 1295 ('63).

211) 岸本賢一，安盛善一：分化，12，125 ('63); 212) C. E. H. Knapman, D. Ambrose, ed.: "Gas Chromatography Abstracts, 1962", ('63), (Butterworths, Inc., Washington); 213) C. H. E. Knapman, C. G. Scott ed.: “ibid., 1961 ”, ('62), (Butterworths, Inc., Washington); 214) B. A. Knights, G. H. Thomas: Chem. Ind. (London), 1963, 43; 215) B. A. Knights, G. H. Thomas: J. Chem. Soc., 1963, 3477; 216) 
B. A. Knights, G. H. Thomas: Nature, 194, 833 ('62); 217) J. H. Knox: "Gas Chromatography ", ('62), (Methuen, London, Wiley, New York); 218) J. H. Knox, L. McLaren: Anal. Chem., 35, 449 ('63); 219) F. J. Kobat, L. S. Ettre: J. Gas Chromatog., 2, (1), 21 ('64); 220) 小橋友助, 宝積寿子, 渡辺美秿子: 日化, 84, 419('63). 221）小橋友助，渡辺美穂子，山下雄右：農化，37, 291 ('63) ; 222) E. Kucera, O. Grubner: "GasChromatographie, 1963', H. P. Angele and H. G. Struppe, ed., p. 351 ('63), (Akademie-Verlag, G. m. b. H., Berlin); 223) R. H. Kolloff: Anal. Chem., 34, 1840 ('62)；224）里田 勲, 小泉淳二, 世一義隆: 分化, 12, 177 ('63); 225) R. A. Landowne, S. R. Lipsky: Anal. Chem., 35, 532 ('63); 226) R. A. Londowne, S. R. Lipsky: ibid., 34, 726 ('62); 227) R. A. Landowne, S. R. Lipsky: Nature, 199, 141 ('63); 228) D. D. Lawson, A. J. Havlik: J. Gas Chromatog., 1, (5), 17('63) ; 229) W. Leipnitz, H.G. Konnecke: J. Prakt. Chem., 18, 110 ('62); 230) S. Z. Lewin: J. Chem. Educ., 39, A83 ('62).

231) S. Z. Lewin: J. Chem. Educ., 39, A161 ('62); 232) J. S. Lewis: "Compilation of Gas Chromatographic Data", ASTM Spec. Tech. Publ. No. 343 ('63), (American Society for Testing Materials, Philadelphia, Pa); 233) K. I. Lieser, H. Elias, F. Sorg: Z. Anal. Chem., 191, 104 ('62); 234) S. R. Lipsky, M. M. Shahin: Nature, 197, 625 ('63); 235) C. Litchfield, R. Reiser, A. F. Isbell: J. Am. Oil Chemists Soc., 40, 302 ('63); 236) A. B. Littlewood: “Gas Chromatography", ('62), Academic Press, New York); 237) A.B. Littlewood: J. Gas Chromatog., 1, (5), 6 ('63); 238) A. B. Littlewood: ibid., 1, (11), 16 ('63); 239) A. B. Littlewood: ibid., 1, (11), 34 ('63); 240) J. E. Lovelock, G. R. Shoemake, A. Zlatkis: Anal. Chem., 35, 374 ('63).

241) H. Luy: Z. Anal. Chem., 194, 241 ('63); 242) I. Lyski, H. G. Offner, V. E. Bedwell: J. Chromatog., 11, 320 ('63); 243) D.B. McComas, A. Goldfien: Anal. Chem., 35, 263 ('63); 244) H. L. McDonell, J. M. Noonan, J. P. Williams: ibid., 35, 1253 ('63) ; 245) D. J. McEwen: ibid., 35, 1636 ('63); 246) D. J. McEwen: J. Chromatog., 9, 266 ('62); 247) R. W. McKinney, J.H. Baird: J. Gas Chromatog., 1, (5), 16 ('63); 248) D. A. McQuarrie: J. Chem. Phys., 38, 437 ('63); 249) I. G. McWilliam: J. Chromatog., 6, 359 ('61); 250) H. J. Maier, O. C. Karpathy: ibid., 8, 308 ('62).

251) H. F. Martin, J. L. Driscoll, B. I. Gudzinowicz: Anal. Chem., 35, 1901 ('63); 252) J. L. Martin: Analyst, 88, 326 ('63); 253) R. L. Martin: Anal. Chem., 35, 116 ('63); 254) 前 子洋一郎：化学の領域増刊, 49,115 ('62); 255) 松 田 勗，矢次英夫：分化，11，1116 ('62); 256) 松 隈 昭：日化, 84, 774 ('63); 257) 松岡徹, 山田 昭三：分化，12，958 ('63); 258) R. Mecke, K. Zirker: J. Chromatog., 7, 1 ('62); 259) C. Merritt, Jr., J. T. Walsh: Anal. Chem., 34, 903 ('62); 260) C. Merritt, Jr., J. T. Walsh: ibid., 35, 110 ('63).

261) J. Merritt, F. Comendant, S.T. Abrams, V. N. Smith: Anal. Chem., 35, 1461 ('63); 262)

L. D. Metcalfe: J. Gas Chromatog., 1, (1), 7 ('63); 263) J. Middlehurst, B. Kennett: J. Chromatog., 10, 294 ('63); 264) J. M. Miller:

“Experimental Gas Chromatography", ('63), (Gow-Mac. Instrument Co., Madison, N. J.); 265) D. J. Morgan: J. Sci. Instr., 38, 501 ('61); 266) 森田修吾，東谷 博：分化，11，282('62)；267) J. V. Mortimer, P. L. Gent: Nature, 197, 789 ('63); 268) L. J. Myers: Anal. Chem., 35, 119 ('63); 269) D. H. Napier, J. R. Simonson: Chem. Ind. (London), 1962, 1831; 270) D. C. Nelson, D. L. Paull: Anal. Chem., 35, 1571 ('63).

271) A. G. Nerheim: Anal. Chem., 35, 1640 ('63); 272) E. W. Neumann, H. G. Nadeau: ibici., 35, 1454 ('63); 273) J. G. Nikelly: ibid., 34，472（'62）；274） 日本分析化学会編：ガスクロマ トグラフィー・データカード，第 1 第 4 期 (櫝書店); 275) 西 末雄：分化, 11, 415 ('62); 276) S. D. Norem: Anal. Chem., 34, 40 ('62); 277) F. Nyman, H. L. Roberts: J. Chem. Soc., 1962, 3180；278）小田仲枇, 則島勝典, 内島宏和：分化, 12,461 ('63); 279) 萩庭大寿, 原田正敏, 中島藟 之, 境 一之: 薬誌, 82, 1441 ('62); 280) R. W. Ohline, D. D. Deford: Anal. Chem., 35, 227 ('63).

281）Oil Gas J., 60, (40)，55 ('62)；282) 大岩 恒夫，佐藤松次，宮川吉隆，宮島郁夫：日化, 84, 409 ('63); 283) H. J. O'Nell, R. E. Putscher, A. Dynako, C. Boquist: J. Gas Chromatog., 1, (2), 28 ('63)；284) 大梘 晃, 半谷高久: 日化, 84, 798 ('63); 285) D. M. Ottenstein: J. Gas Chromatog., 1, (4), 11 ('63); 286) D. S. Payn, W. D. Keardon, L. J. Harvey: Nature, 200, 467 ('63); 287) G. Perkins, Jr., R. E. Larany, L. D. Liverly: Anal. Chem., 35, 360 ('63); 288) R. H. Perrett, J. H. Purnell: ibid., 34, 1336 ('62); 289) R. H. Perrett, J. H. Purnell: ibid., 35, 430 ('63) ; 290) R.H. Perrett, J.H. Purnell: J. Chromatog., 7, 455 ('62).

291) D. L. Petitjean, C. J. Leftault, Jr.: J. Gas Chromatog., 1, (3), 18 ('63); 292) C. S. G. Phillips, P. L. Timms: Anal. Chem., 35, 505 ('63); 293) O. Piringer, M. Pascalau: J. Chromatog., 8, 410 ('62); 294) S. Polezzo, M. Taramasso: ibid., 11, 19 ('63); 295) C. G. Pope: Anal. Chem., 35, 654 ('63); 296) P. J. Porcaro: J. Gas Chromatog., 1, (6), 17 ('63); 297) R.S. Porter, A.S. Hoffman, J.F. Johnson: Anal. Chem., 34, 1179('62); 298) S.T. Preston: J. Gas Chromatog., 1, (3), 8 ('63); 299) S. T. Preston, Jr., G. Hyder: "Comprehensive Bibliography and Index to the Literature on Gas Chromatography", ('64), (Preston Tecinical Abstracts Co., Evanston, III.); 300) S. T. Preston, Jr., G. Hyder: J. Gas Chromatog., 1, (3), 22 ('63); ibid., 1, (4), 24 ('63).

301) S.T. Preston, Jr., G. Hyder, G. Mignon: J. Gas Chromatog., 1, (12), 24 ('63); 302) Preston Technical Abstracts Co., 1718 Sherman. 
Ave, Evanston, III., Card abstracts; 303) Process Control Automation, 9, 424 ('62); 304) J. H. Purnell: “Gas Chromatography", ('62), (Wiley, New York); 305) R. F. Putnam: Anal. Chem., 34, 718 ('62); 306) E.R. Quiram: ibid., 35, 593 ('63); 307) C. N. Reilley, G. P. Hildebrand, J. W. Ashley: ibid., 34, 1198 ('62); 308) A. Renshaw: J. Chromatog., 8, 343 ('62); 309) J. W. Robson, W. B. Askew: ibid., 7, 409 ('62) ; 310) L. B. Rogers, A. G. Altenau: Anal. Chem., 35, 915 ('63).

311) L.B. Rogers, J.C. Spitzer: Anal. Chem., 33, 1959 ('61); 312) W. D. Ross: ibid., 35, 1596 ('63); 313) R. Rowan: ibid., 34, 1042 ('62); 314) H. Runge: Z. Anal. Chem., 189, 111 ('62); 315) A. S. Said: J. Gas Chromatog., 1, (6), 20 ('63) ; 316) A. S. Said, M. A. Robinson: ibid., 1, (9), 7('63); 317) L. Saint-Rat, D. Bertrand: ibid., 1, (4), 31 ('63); 318) 佐藤秀之訳：(A. I. M. Keuleman 著) ガスクロマトグラフィー, ('62), (丸善); 319) H. Schlenk, J. L. Gellerman, D. M. Sand: Anal. Chem., 34, 1529 ('62); 320) H. Schlenk, D. M. Sand: ibid., 34, 1676 ('63).

321) G. Schomburg: Z. Anal. Chem., 189, 14 ('62); 322) R. D. Schwartz, D. J. Brasseaux, G. R. Shoemake: Anal. Chem., 35, 496 ('63); 323) R. D. Schwartz, D. J. Brasseaux, G. R. Shoemake: J. Gas Chromatog., 1, (1), 32 ('63); 324) C. G. Scott: Nature, 193, 159 ('62); 325) R. P. W. Scott: Anal. Chem., 35, 481('63) ; 326) R. P. W. Scott: Nature, 198, 782 ('63); 327) S. L. Seager, L. R. Geertson, J. C. Giddings: J. Chem. Eng. Data, 8, 168 ('63); 328) T. Seiyama, A. Kato, K. Fujiishi, M. Nagatani: Anal. Chem., 34, 1502 ('62); 329) M. M. Shahin, S. R. Lipsky: ibid., 35, 467 ('63); 330) 白浜升章, 桜木雄二郎: 日化, 84, 267 ('63).

331) F. Sicilio, J. A. Knight: J. Chromatog., 6, 243 ('61); 332) R.E. Sievers, R.M. Moshier, M. L. Morris: Inorg. Chem., 1, 966 ('62); 333) R. E. Sievers, B. W. Ponder, M. L. Morris, R. W. Moshier: ibid., 2, 693 ('63); 334) A. V. Signeur: "Guide to Gas Chromatography Literature", 250pp. ('63), (Plenum Press, New York); 335) P. G. Simmonds, J. E. Lovelock: Anal. Chem., 35, 1345 ('63); 336) J.F. Smith: Chem. Ind. (London), 1960, 1024; 337) B. Smith, R. Ohlson, G. Larson: Acta Chem. Scand., 17, 436 ('63); 338) E. D. Smith, A. B. Gosnell: Anal. Chem., 34, 646 ('62); 339) V. N. Smith, E. J. Merritt: ibid., 34, 1476('62); 340) J. Spolnicki, W. M. Crooks: J. Appl. Chem. (London), 13, 12 ('63).

341) J. Spolnicki, W. M. Crooks: J. Appl. Chem. (London), 13, 232 ('63); 342) R. K. Stevens, J. D. Mold: J. Chromatog., 10, 398 ('63); 343) W. R. Supina: Anal. Chem., 35, 1304 ('63); 344) 鈴木祝寿: 分化, 11, 618 ('62); 345) M.H. Swann, M.L. Adams, G.G. Esposito: Anal. Chem., 35, (5), 35R ('63); 346) C. C. Sweeley, R. Bentley, M. Makita, W.W. Welk: J. Am. Chem. Soc., 85, 2497 ('63); 347) J. W. Swinnerton, V. J. Linnenbom, C. H. Creek:
Anal. Chem., 34, 483 ('62); 348) J. W. Swinnerton, V. J. Linnenbom, C. H. Creek: ibid., 34, 1509 ('62); 349) P. A. T. Swoboda: Nature, 199, 31 ('63); 350) H. A. Szymanski ed.: "Lectures on Gas Chromatography, 1962", 288pp. ('62), (Plenum Press, New York).

351) J. Tadmor: "Chromatographic Reviews ", Vol. 5, Michael Lederer, ed., p. 223 ('63), (Elsevior, New York); 352) 高島 孷, 古賀 全, 金子順二: 工化, 65, 1223 ('62); 353) 竹田一郎: 同上, 66, 442 ('63); 354) 竹田一郎, 益子洋一郎: 同上, 66, 446 ('63); 355) 武内次夫, 石井大道, 柘 植 新: 同上, 66, 1295 ('63); 356) 武内次夫, 石 井大道，柘植 新：同上，66, 1299 ('63); 357) 武 内次夫, 藤島 篇, 柘植 新: 分化, 13, 449 ('64); 358) 武内次夫, 説田 勉: 工化, 66, $106\left({ }^{\prime} 63\right)$; 359) 武内次夫，説田 勉：同上, 66, $\left.1799\left({ }^{\prime} 63\right) ; 360\right)$ 武 内次夫，鈴木義仁：同上，66，1855 ('63).

361) 武内次夫, 高山雄二: 機器分析実験法講座, 7 巻 ('64), (オーム社); 362) P. Teisseire: Bull. Soc. Chim. France, 1963, 384; 363) M. Tenenbaum, F. L. Howard: J. Res. Nat. Bur. Std., 66A (3)，255 ('62); 364) 寺田博次, 津田晋 三, 庄野唯衛: 工化, 65, 1569 ('62); 365) R. Teranishi, J. Corse: J. Chromatog., 9, 244('62); 366) H. A. Thijssen: ibid., 11, 141 ('63); 367) A. E. Thompson: ibid., 6, 454 ('61); 368) T. O. Tiernan, J. H. Futrell: Anal. Chem., 34, 1838 ('62); 369) G. M. Touayheb, O.F. Folmer, W. C. Hamilton: Anal. Chim. Acta, 26, 373 ('62); 370) S. Turia, V. Krajovan, T. Kastamaj: Z. Anal. Chem., 189, 100 ('62).

371) C. M. Tyler: Chem. Eng. Progress, 58, (9), 51 ('62); 372) 内田 章, 松田住雄: 工化, 65, 574 ('62); 373) P. Urone, R. J. Katnik: Anal. Chem., 35, 767 ('63); 374) H. van den Dool, P. D. Kratz: J. Chromatog., 11, 463 ('63); 375) F. A. Vandenheuvel: Anal. Chem., 35, 1193 ('63); 376) W. J. A. Vanden Heuvel, W. L. Gardiner, E. C. Horning: ibid., 35, 1745 ('63); 377) W. J. A. Vanden Heubel, H. C. Horning: Biochem. Biophys. Acta, 64, 416 ('62); 378) M. Van der Stricht, J. Van Rysselberge: J. Gas Chromatog., 1, (8), 29 ('63); 379) M. van Swaay, ed.: "Gas Chromatography, 1962", 411pp. ('62), (Butterworths, Washington); 380) P. F. Váradi, K. Ettre: Anal. Chem., 34, 1417 ('62).

381) P. F. IVáradi, K. Ettre: Anal. Chem., 35, 410 ('63); 382) M. J. Verzele: J. Chromatog., 9, 116 ('62); 383) O. Weber: Z. Anal. Chem., 194, 334 ('63); 384) W. E. Wentworth, R. S. Becker: J. Am. Chem. Soc., 84, 4263('62); 385) W. E. Westlake: Anal. Chem., 35, (5), 105R ('63); 386) K. Widmark, G. Widmark: Acta Chem. Scand., 16, 575 ('62); 387) J. Wilkinson, D. Hall: J. Chromatog., 10, 239 ('63); 388) D. D.Williams, R. R. Miller: Anal. Chem., 34, 657 ('62); 389) J. Winkelman, A. Karmen: ibid., 34, 1067 ('62); 390) W. A. Wiseman; Nature, 192, 964 ('61).

391) J. W. Wisniewski, S. F. Spencer: J. Gas Chromatog., 2, (1), 34 ('64); 392) J. L. 
Wright: ibid., 1, (11), 10 ('63); 393) M. Yamane: J. Chromatog., 9, 162 ('62); 394) M. Yamane: ibid., 11, 158 ('63); 395) 安盛善一, 岸 本賢一：化学の領域増刊, 49, 153 ('62); 396) 吉見 直喜, 山尾正義, 河北雅之, 田中誠之：工化，66, 279 ('63); 397) 吉見直喜, 山尾正義, 田中誠之：同上, 66, 286 ('63); 398) 吉見直喜, 山尾正義, 田中誠之: 同上, 66, 1601 ('63); 399) 吉見直喜, 山尾正義, 河北雅之，田中誠之：同上，66，283('63)；400) 吉 見直喜, 山尾正義, 河北雅之, 田中誠之：同上, 66, 1131 ('63).

401）吉見直喜, 山尾正義, 河北雅之, 田中誠之：工
化, 66, 1484 ('63); 402) 吉本敏雄: 日化, 83, 961 ('62)； 403) 吉本敏雄: 同上, 83, 966 ('62); 404) 吉村 実, 出来三男：分化，12，941 ('63)；405) A. Zlatkis, J. Q. Walker: Anal. Chem., 35, 1359 ('63); 406) A. Zlatkis, J. Q. Walker: J. Gas Chromatog., 1, (5), 9 ('63); 407) C. Zomzely, G. Marco, E. Emery: Anal. Chem., 34, 1414 ('62) ; 408) J. Zulaica, G. Guiochon: ibid., 35, 1724 ('63); 409) J. Franc, S. Michajlova: J. Chromatog., 12, 22 ('63); 410) D. C. Nelson, P. C. Ressler, Jr., R. C. Hawes: Anal. Chem., 35, 1575 ('63).

\section{0 溶媒抽出分析 \\ 金 森 悟*.田中 元治**}

1962 年および 1963 年に発表された溶媒抽出に関する 研究の数は 2000 以上に達し，おそらく実用分析の一段 階として抽出分離を用いた研究を加えればその数は倍加 するであろう. Anal. Chem. にはこの 2 年間の論文の 非常に広範な総説1)がある.

これらの論交を通覧して目立つ点は第一にキレート抽 出系では平衡論的な理論がほぼ確立され, 実用分析のみ でなく溶液内の化学平衡を取扱うための一つの有力な手 段となりつつあることである. 第二にこれに比較して注 目すべきは，TBP およびアミンに関係した研究の数が 急激に増加し, 主としてウラン, トリウム, ジルコニウ ムおよびハフニウムの抽出機構が論じられていることで ある・

以上の諭文をすべてここで取りあげることは不可能で あるから，この進歩総説の他の分野で取りあげられる可 能性のあるものは割愛し, 分析化学的応用の基礎となる ような題目をおもに取り上げた。

\section{$10 \cdot 1$ 総 説}

Marcus $^{2)}$ によってすぐれた総説が報告されており， 特に溶媒抽出法の系統的な分類においてすぐれている. その他抽出平衡の 数学的取り扱いについて 硝酸ウラニ ル3) 㧍よび金属ハロゲン化物その他の抽出化学種4)関 する報告があり，分配係数と抽出熱との関係についても

* 名古屋大学理学部水質研究施設（名古屋市千種区 不老町)

** 名古屋大学理学部化学教室 (名古屋市千種区不老 町)
報告されている5). また溶媒抽出法のポーラログラフィ 一6)および光度法7へへの応用や微量元素の定量への応 用8）に関する統説もある. その他スカンジウム，ネオシ ムなどのオキシン抽出の際のカルシウムやストロンチウ ムの共抽出に関する総説910)があり，また，有機アミン 化合物およびアルキルりン化令物などの液状イオン交換 体に関する総説11) 13)が市る。

\section{$10 \cdot 2$ 中性分子打よび無機酸の抽出}

中性分子の分配についてはゲルマニウム (IV) および スズ(IV) の塩化物およびョウ化物の研究があり，塩析 効果に注意が向けられている14) 16). また四酸化オス之 ウムの分配17およびハロゲンの向流分配に対するハロゲ ン化物イオンの影響18)に関する報告がある. 無機酸の有 機りン化合物およびアミン化合物以外による抽出に関し てはチオシアン酸19) 21), 塭酸19), 硫酸19), リン酸22)23), 硝酸24)およびホウ酸25)26)の炭化水素, アルコール，エー テル，エステルおよびケトンによる抽出の報告がある. これらのなかには塩析を取报ったもの23225)もあり，ま た，チオシアン酸のアセトフェノンによる抽出では錯体 の生成定数が測定 ${ }^{20) さ れ て い る . ~}$

$$
10 \cdot 3 \text { キレートの抽出 }
$$

クペロン27およびオキシン28)29)による抽出については 広範な系統的な研究があって実用分析の参考になる.

キレート抽出系を理論的に取り扱った報告も多数あ り，物理化学的測定の有用な手段として役立っている例 も少くない。すなわち， ウラン(VI) およびネブッニウ 